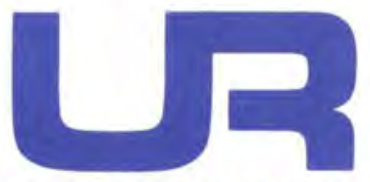

UNITED STATES

URANIUM REGISTRY

\title{
Occupational Exposures to Uranium: Processes, Hazards and Regulations
}

A Field Study of the Commercial Fuel Cycle

April 1981

Prepared by the Hanford Environmental Health Foundation and Pacific Northwest Laboratory for the U.S. Department of Energy 


\title{
NOTICE
}

This report was prepared as an account of work sponsored by the United States Government. Neither the United States nor the Department of Energy, nor any of their employees, nor any of their contractors, subcontractors, or their employees, makes any warranty, express or implied, or assumes any legal liability or responsibility for the accuracy, completeness or usefulness of any information, apparatus, product or process disclosed, or represents that its use would not infringe privately owned rights.

The views, opinions and conclusions contained in this report are those of the contractor and do not necessarily represent those of the United States Government or the United States Department of Energy.

\author{
PACIFIC NORTHWEST LABORATORY \\ operated by \\ BATTELLE \\ for the \\ UNITED STATES DEPARTMENT OF ENERGY \\ Under Contract DE-AC06-76RLO 1830
}

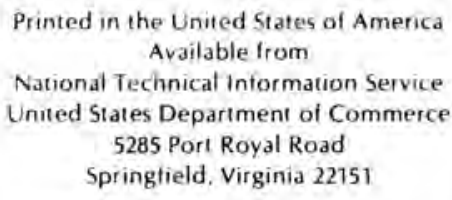




\section{Occupational Exposures to Uranium: Processes, Hazards and Regulations}

\section{A Field Study of the Commercial Fuel Cycle}

Pacific Northwest Laboratory

G.A. Stoetzel

D.R. Fisher

W.D. McCormack

G.R. Hoenes

S. Marks, Program Coordinator
Hanford Environmental Health Foundation

R.H. Moore

D.G. Quilici

B.D. Breitenstein, Program Coordinator

Prepared by the Hanford Environmental Health Foundation and Pacific Northwest Laboratory for the U.S. Department of Energy 


\section{ACKNOWLEDGMENTS}

The authors wish to thank the many individuals in the uranium industry who took time from their schedules to participate in the information-gathering phase of the Uranium Registry. The information gathered through site visits and telephone conversations was invaluable in preparing this report.

The authors also wish to acknowledge the contribution of $F$. T. Cross and D. W. Murphy of Pacific Northwest Laboratory, who assisted in the preparation and review of this report, J. L. Baer, who edited the report, and M. Cross, who typed the report. 
b

, 


\section{EXECUTIVE SUMMARY}

The United States Uranium Registry (USUR) was formed in 1978 to investigate potential hazards from occupational exposure to uranium and to assess the need for special health-related studies of uranium workers. The need for information on the behavior and effects of uranium in man was emphasized at the U.S. Energy Research and Development Administration's conference on occupational health experience with uranium in 1975. In response to this need, the U.S. Department of Energy provided funding to the Hanford Environmental Health Foundation to establish the USUR. Pacific Northwest Laboratory was identified to provide technical support in the area of health physics.

The major goals of the Registry are:

- to characterize the processes and the occupational health aspects of the uranium fuel cycle

- to determine the concentration and distribution of uranium and its decay daughters in the tissues of exposed workers

- to identify populations suitable for special health-related studies.

Personnel working for the USUR have visited 35 uranium facilities to collect information toward accomplishment of these goals. Facilities visited include currently operating commercial uranium facilities (mines, mills, conversion plants, enrichment plants, and fuel fabrication plants), and several noncommercial and inactive uranium facilities. Information obtained to date covers general facility descriptions, process descriptions, radiological exposures, regulatory requirements, radiological health practices, nonradiological exposures, and occupational medicine programs. The informationgathering phase of the program reinforced the original sense that a post-mortem tissue program for uranium workers is needed. The current lack of information on the deposition, distribution, and retention of various uranium compounds in man greatly increases the difficulty of developing appropriate standards for uranium exposure and, consequently, worker protection policies. The tissue program will in due course provide that information. 
Following is a brief summary of the data collected during the informationgathering phase, and the current status of the tissue program.

\section{RADIOLOGICAL EXPOSURES}

Inhalation is the most important pathway for occupational exposure in the commercial uranium industry. External radiation exposures are not considered to be as significant. Workers in the industry may inhale many different uranium compounds.

- Mines - The major hazard in underground uranium mines is inhalation of radon daughter products. Past studies have shown increased incidence of lung cancer among miners due to radon daughters. Inhalation of radon daughters at open-pit mines is generally negligible because of the diluting effect of the atmosphere.

- Mills - At conventional uranium mills, the primary concerns are inhalation of ore dust in ore crushing areas and inhalation of yellowcake dust in the drying and packaging areas. Both production and maintenance personnel who work in these areas have a potential for exposure.

- Conversion facilities - At conversion facilities, inhalation of the following uranium compounds is possible: yellowcake, uranium tetrafluoride $\left(\mathrm{UF}_{4}\right)$, uranium dioxide $\left(\mathrm{UO}_{2}\right)$, uranium trioxide $\left(\mathrm{UO}_{3}\right)$, and uranyl fluoride $\left(\mathrm{UO}_{2} \mathrm{~F}_{2}\right)$ which is formed when $\mathrm{UF}_{6}$ reacts with the atmosphere. Activities with the greatest potential for inhalation exposures include yellowcake sampling, waste removal, and maintenance.

- Enrichment facilities - The greatest potential for inhalation exposures in enrichment facilities is from inadvertent uranium hexafluoride $\left(U_{6}\right)$ releases during sampling, $U_{6}$ cylinder loading and unloading, and maintenance operations.

- Fuel fabrication facilities - In the fuel fabrication industry, the primary inhalation hazard is exposure to $\mathrm{UO}_{2}$ during packaging and unpackaging, powder handling and pelletizing, and maintenance. 


\section{REGULATION OF THE COMMERCIAL URANIUM INDUSTRY}

The current industry is regulated by numerous federal and state agencies. For example, the Mine Safety and Health Administration and state agencies regulate uranium mines whereas the Nuclear Regulatory Commission or agreement state agencies regulate uranium mills. This simultaneous regulation by many agencies has resulted in inconsistencies among radiation protection programs at similar types of facilities because the same regulations may be interpreted and enforced in different ways by independent regulatory bodies.

\section{RADIOLOGICAL HEALTH PRACTICES}

Facility monitoring, exposure control, exposure evaluation, and recordkeeping are the four general methods used to identify and control radiation hazards in the commercial uranium industry.

- Facility monitoring - Air in the breathing zone is monitored for suspended uranium nuclides, and working locations are surveyed for surface contamination or any accumulation of gamma-emitting materials. The selection of monitoring locations and the frequency of sampling or measurements are determined by consideration of the quantities of radioactive materials in the production processes, their potential for escape from the system into the workplace, and their proximity to the worker.

- Exposure control - Exposure control is achieved through design engineering to prevent and control releases, respiratory protection programs, the use of protective clothing, and worker training programs.

- Exposure evaluation - Exposure evaluation methods include bioassay (urinalysis and lung counting) for estimating internal depositions of uranium, and personal external gamma monitoring. The frequency of urinalysis for uranium varies among the uranium facilities. Routine lung counting is only performed at conversion, enrichment, and fuel fabrication facilities. 
- Recordkeeping - Recordkeeping involves maintaining records of facility monitoring and exposure evaluation data. Regulatory agencies require each licensed facility to maintain such records.

Uranium can present both a radiological and a chemical hazard to the body. The chemistry of a uranium compound determines its solubility in body fluids and its retention time in the tissues. For example, yellowcake consists of varying percentages of the soluble uranium compound ammonium diuranate, and the insoluble uranium compound $\mathrm{U}_{3} \mathrm{O}_{8}$, depending on the temperature at which the yellowcake is dried. Both soluble and insoluble forms of uranium may accumulate in different parts of the body through chronic exposure and remain there for long periods, resulting in a radiological hazard. Soluble forms also represent a chemical hazard to kidney tissue. The solubility of inhaled uranium compounds is only one of many factors that need to be considered to achieve even a crude estimate of dose from internally deposited uranium.

\section{NONRADIOLOGICAL EXPOSURES}

Nonradiological exposures in the uranium industry have been identified as a part of this study because they may affect the interpretation of the health effects of radiological exposures. An example is the impact of diesel emissions and cigarette smoking on underground miners, which is being studied by other investigators. Indeed, nonradiological exposures to substances such as silica, which is present in the mining phase of the industry, may have more important and far-reaching effects on worker health than radiological exposures. In other phases of the industry, ammonia is thought to present the greatest single potential for exposure. Exposures to a variety of other chemicals and gases are possible; however, concentrations are generally not at levels thought to be a health hazard.

\section{U.S. URANIUM REGISTRY TISSUE PROGRAM}

An important accomplishment of the USUR has been to establish a postmortem tissue program. The program represents the first systematic effort to contact and gain the cooperation of workers exposed to uranium. The primary objectives of the program are to: 
- determine the distribution and levels of uranium in the tissues of occupationally exposed workers

- compare bioassay measurements of exposed individuals with the results of analyses of tissue obtained at autopsy

- seek evidence of histopathologic changes related to any uranium deposition that may be present.

Procedures have been established for enrolling workers, identifying the tissues to be sampled, and analyzing the samples. Active enrollment of workers is now under way. 


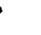

(

• 


\section{CONTENTS}

ACKNOWLEDGMENTS

EXECUTIVE SUMMARY

INTRODUCTION

SCOPE OF URANIUM REGISTRY ACTIVITIES

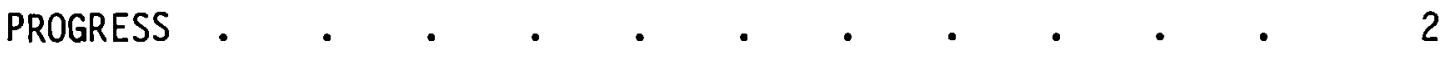

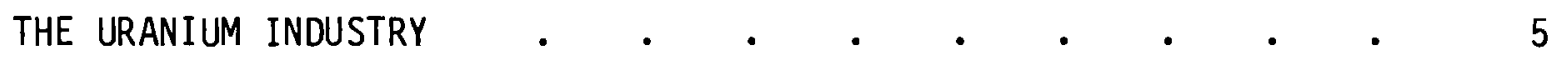

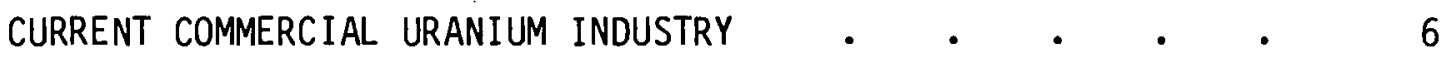

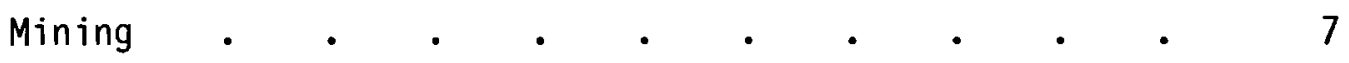

Milling . $\quad . \quad$. $\quad . \quad$. $\quad . \quad$. 12

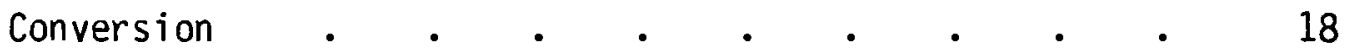

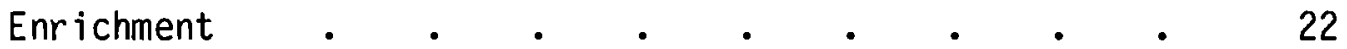

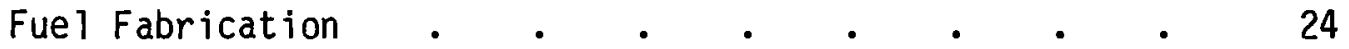

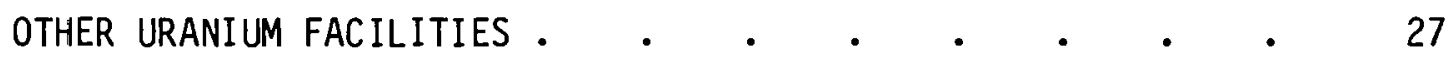

Inactive Facilities . $\quad . \quad$ - $\quad$ - . $\quad 28$

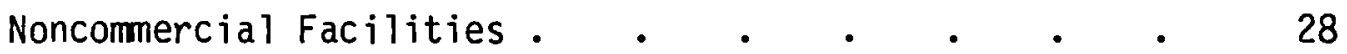

REGULATION OF THE COMMERCIAL URANIUM INDUSTRY $\quad$ • $\quad$ • $\quad$ • 29

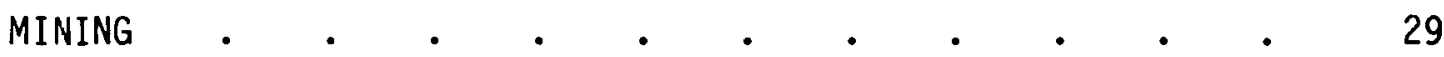

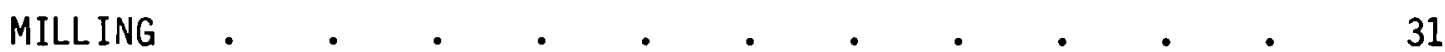

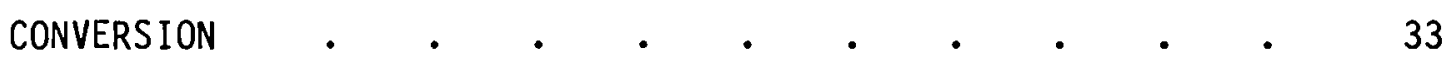

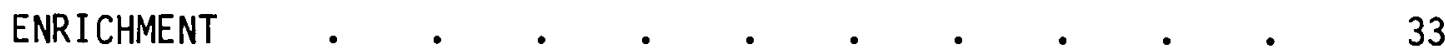

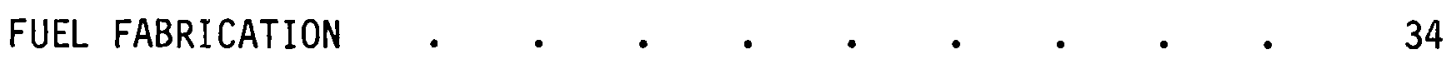

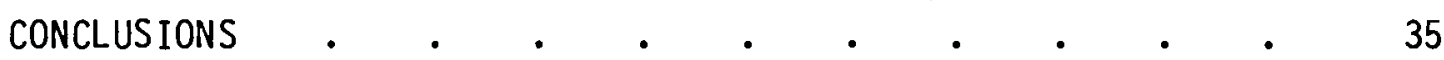

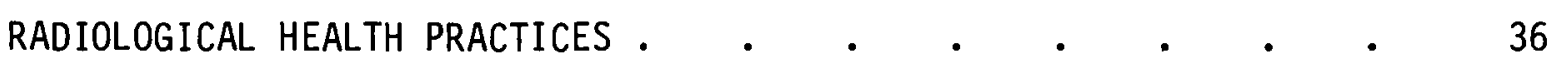

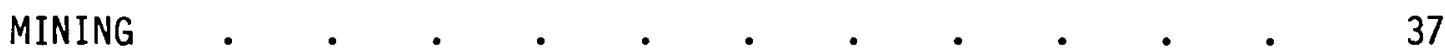

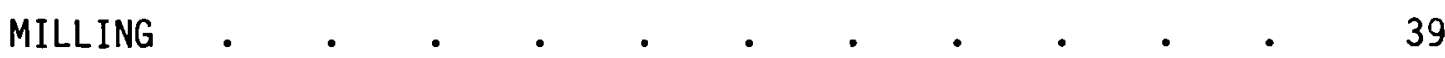




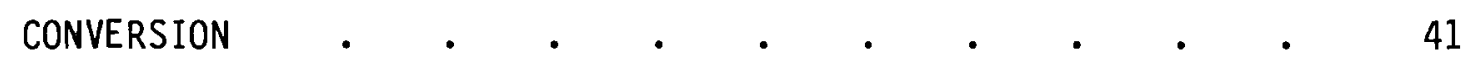

ENRICHMENT

FUEL FABRICATION

NONRADIOLOGICAL ASPECTS OF THE URANIUM INDUSTRY $\quad$. $\quad$ • 46

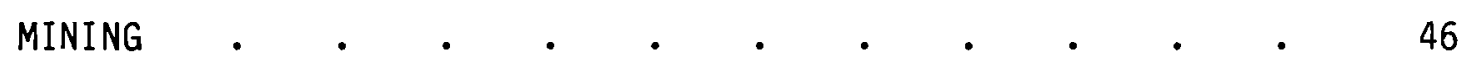

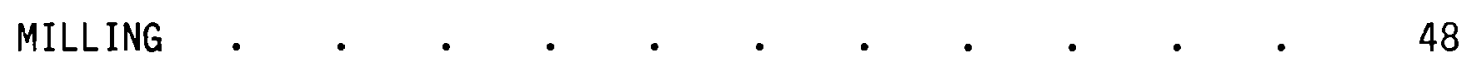

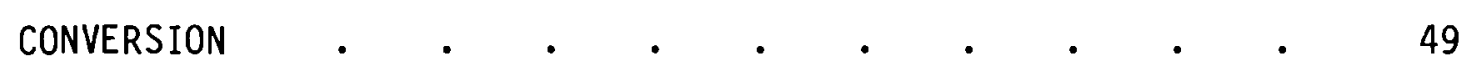

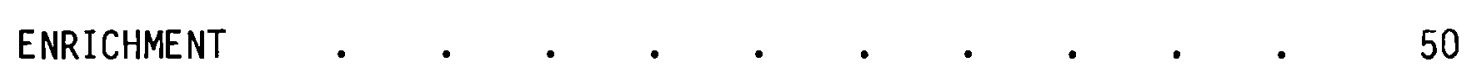

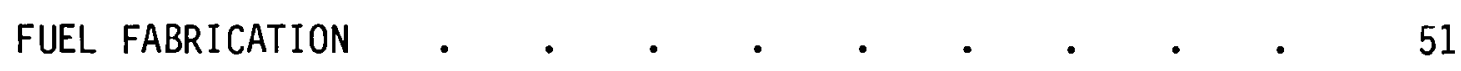

U.S. URANIUM REGISTRY TISSUE PROGRAM . . . . . . . . . . 53

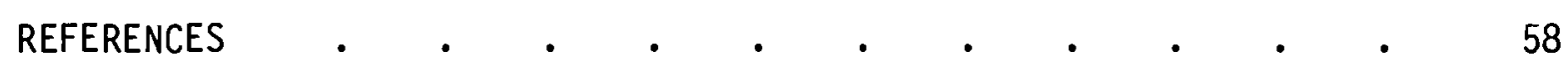

APPENDIX A FACILITIES VISITED BY URANIUM REGISTRY PERSONNEL A. A.1

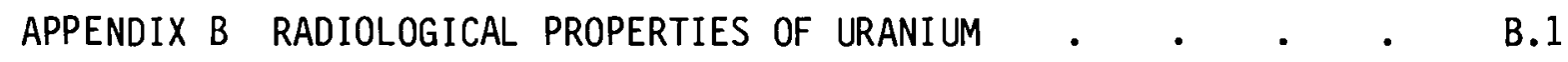

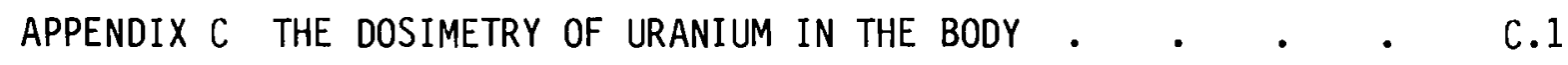




\section{FIGURES}

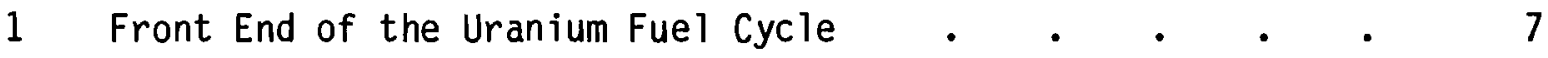

2 Uranium Resource Regions of the United States . . . 9

3 Uranium Mills in the United States Operating as of 1/1/80 . 14

4 Flow Diagram of Basic Conventional Milling Steps . . . 16

5 Flow Diagram of Conversion Processes . . . . . 20

6 Flow Diagram of Enrichment Process . • • • . 23

7 Flow Diagram of Fuel Fabrication Process . • • • . 26

B.1 Uranium-238 Decay Series . . . . . . . . B.3

TABLES

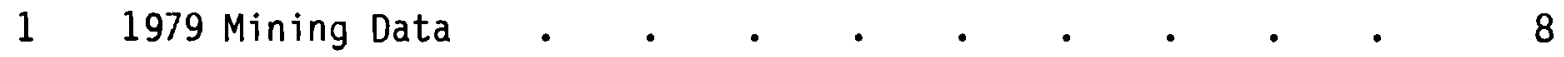




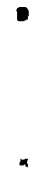

^

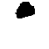


OCCUPATIONAL EXPOSURES TO URANIUM:

PROCESSES, HAZARDS, AND REGULATIONS

A FIELD STUDY OF THE COMMERCIAL FUEL CYCLE

\section{INTRODUCTION}

Since the birth of the uranium industry during the Manhattan Project of World War II, the industry has experienced continued expansion, in response first to increased military needs, and later to a growing nuclear power industry. Today, several thousand workers are employed in the many different types of uranium-handling and uranium-processing facilities.

The total radiation exposure of the worker population in the uraniumhandling industry constitutes a significant portion of the occupational exposures throughout the nuclear industry. During the early years, industry conditions often led to worker exposures that would be considered excessive by today's standards. Since that time, much data has been collected on uranium metabolism in animals; however, as the conference on occupational health experience with uranium (U.S. Energy Research and Development Administration (ERDA) 1975) pointed out, information on the behavior and effects of uranium in man is needed.

In response to this need and to long-term and widespread occupational exposures to uranium and its related compounds, the United States Uranium Registry was formed.

\section{SCOPE OF URANIUM REGISTRY ACTIVITIES}

In 1978, the U.S. Department of Energy (DOE) provided funding to the Hanford Environmental Health Foundation (HEHF) to establish a United States Uranium Registry (USUR). The Hanford Environmental Health Foundation, a contractor to DOE, provides occupational health, psychology, and environmental health science services to contractor employees at the Hanford Project in Richland, Washington. The Pacific Northwest Laboratory (PNL), operated for 
DOE by Battelle Memorial Institute, was identified to provide technical support and assistance in the area of health physics.

The Registry's purpose is to investigate potential hazards from occupational exposure to uranium and to assess the need for special health-related studies of uranium workers. The Registry can provide a center for the collection and evaluation of data on the uptake, translocation, and retention of uranium and related nuclides in occupationally exposed individuals. It could also function as a clearinghouse for information and data for related programs and research. Specific goals of the Registry are:

- to characterize the uranium fuel cycle

- to evaluate the adequacy of documented studies on health effects

- to determine the concentration and distribution of uranium and its decay daughters in the tissues of exposed workers

- to provide information and recommendations for improving the measurement, dosimetry, and control technology of uranium

- to identify populations suitable for special health-related studies.

\section{PROGRESS}

To meet these goals, the Registry has thus far completed the following tasks:

- visited numerous uranium facilities

- described the uranium facilities and their associated processes

- characterized the magnitude and nature of worker exposure to uranium and related materials

- identified occupational exposures to substances other than uranium in the uranium industry

- described and evaluated methods currently used to measure and evaluate uranium exposures

- established a program for post-mortem tissue analysis of workers occupationally exposed to uranium. 
U.S. Uranium Registry representatives have visited 35 facilities. A listing of these facilities is provided in Appendix $A$. Specialists in three disciplines, health physics, industrial hygiene, and occupational medicine, visited each site. Through these site visits, considerable information on the uranium industry was gathered, including process descriptions, areas of greatest potential radiological exposure, regulation of the industry, radiological health practices, and industrial hygiene hazards. This information provided the basis for determining which uranium worker populations are suitable for health-related studies.

The information-gathering phase of the program reinforced the original sense that a post-mortem tissue program for uranium workers is needed. The current lack of information on the deposition, distribution, and retention of various uranium compounds in man greatly increases the difficulty of developing appropriate standards for uranium exposure and, consequently, worker protection policies. The tissue program will in due course provide that information. The data accumulated to date also provide an excellent basis for evaluating the potential for epidemiological studies of uranium exposure in the industry. A report along these lines is projected for future development when additional data immediately relevant to epidemiologic needs become available.

This report provides a summary of Registry work to date. The history of the uranium industry is outlined first, and the current commercial uranium industry (mining, milling, conversion, enrichment, and fuel fabrication) is described. This description includes information on basic processes and areas of greatest potential radiological exposure. In addition, inactive commercial facilities and other uranium operations are discussed. Regulation of the commercial production industry for uranium fuel is reported next, including the historic development of regulations and the current regulatory agencies and procedures for each phase of the industry. A review of radiological health practices in the industry--facility monitoring, exposure control, exposure evaluation, and record-keeping--is then presented. A discussion of the nonradiological hazards of the industry is provided in the next section, and the final section describes the tissue program developed as part of the 
Registry. Appendix $B$ is a general discussion of the radiological properties of uranium, and Appendix $C$ is a review of the factors involved in the dosimetry of uranium in the body.

Three additional reports are projected for completion during fiscal year 1982. They will provide information of the type presented here, but in substantially greater detail, for the following segments of the industry: 1) mining; 2) milling, and 3) conversion, enrichment, and fuel fabrication. Those reports will more adequately reflect the volume of relevant data collected, which could not be encompassed in this initial overview document. 
In 1939, just 150 years after Klaproth discovered the element uranium, nuclear fission was documented and scientists began to visualize the liberation of atomic energy through a self-sustaining fission chain reaction. The first concepts for the uses of atomic energy were for energy production and national security. In June of 1940 , the National Defense Research Committee (NDRC) was established, and in late 1940, the first major contract for government support of atomic research was approved. By late 1941, the findings from the research strongly supported the use of nuclear fission in weapons of immense magnitude, and NDRC recommended on December 6, 1941, that the U.S. government support an all-out effort for an atomic energy program. At that time, the uranium metal produced in the United States was measured in gram or ounce quantities.

In January of 1942, a program was undertaken to obtain uranium metal in quantity. By late 1942, three organizations (Westinghouse, Iowa State College, and Metal Hydrides) had reached a production level of up to 100 pounds $(45 \mathrm{~kg})$ of uranium a week. On December 2, 1942, the chain-reacting pile under the west stand of Stagg Field at the University of Chicago, supplied by these sources, reached criticality. On May 1, 1943, the uranium metal requirements for research and production were taken over by the Manhattan Project (Wilhelm 1960).

The Manhattan Project brought a steadily increasing need for uranium. Approximately two-thirds of it was derived from high-grade Belgian Congo ores and one-third from Canadian and Colorado Plateau ores. The Belgian Congo ores averaged about $25 \%$ uranium, as compared with the $0.11 \%$ uranium averaged in ores mined today. High-grade Belgian Congo ores were received, crushed, and assayed at a U.S. government warehouse in Middlesex, New Jersey. The lower-grade ores from the Colorado Plateau area were obtained from tailings of a vanadium extraction process. The tailings were processed by the Vanadium Corporation of America in Naturita, Colorado, and the U.S. Vanadium Corporation in Uravan and Durango, Colorado. 
The 11 facilities involved in producing nuclear-grade uranium for the Manhattan Project were widely dispersed throughout the United States. The three end products produced at these facilities were uranium metal for the plutonium production reactors at the Hanford Reservation in Washington State, uranium hexafluoride $\left(\mathrm{UF}_{6}\right)$ for isotopic enrichment at the Oak Ridge Gaseous Diffusion Plant in Tennessee, and uranium tetrachloride $\left(\mathrm{UCl}_{4}\right)$ for feed for the calutron magnetic isotopic separators at Oak Ridge (ERDA 1975).

Throughout the 1950s, the demand for uranium for nuclear weapons use led to extensive exploration of uranium-bearing ore deposits. Major deposits were located in the Colorado Plateau area (which includes parts of western Colorado, eastern Utah, northeastern Arizona, and northwestern New Mexico) and the Wyoming Basins (Clark 1974; U.S. Nuclear Regulatory Commission (NRC) 1979; Merritt 1971). These areas are still the major uranium-ore-producing areas in the United States (U.S. Department of Energy (DOE) 1980).

Uranium production decreased in the mid-1960s as the demand for uranium shifted from a military market to a small commercial market. Nuclear power was feasible in the 1960s, but it was not economically competitive with other energy sources (Clark 1974). As a result, the number of active uranium mills and the production rates of those mills decreased considerably. Many uranium exploration activities were also abandoned in the mid-1960s. In the late 1960s, as uranium-fueled reactors for the production of electric power became economically competitive with other power sources, uranium production again increased. Today's uranium production levels are similar to the peak production levels of the early 1960s (DOE 1980). With nuclear power plants currently supplying about $9 \%$ of the U.S. electricity, and predictions that they will provide between $9 \%$ and $20 \%$ by the year 2000 , uranium needs should continue at or above the 1978 levels (NRC 1980).

\section{CURRENT COMMERCIAL URANIUM INDUSTRY}

The commercial uranium industry involves mining uranium ore and converting the uranium concentrate into fuel for nuclear reactors. This segment of the nuclear fuel cycle, commonly referred to as the front end, has several 
stages: mining, milling, conversion, enrichment, and fuel fabrication. These stages are shown pictorially in Figure 1, and the following subsections present for each stage a brief description of the process and the steps most likely to involve radiological exposures to uranium.

\section{Mining}

Mining is the removal of uranium ore from the ground, primarily by openpit and underground methods. In 1979, approximately 15 million tons (13.6 million metric tons $(t))$ of ore with an average $U_{3} 0_{8}$ content of $0.11 \%$ were mined from open-pit and underground mines and shipped to mills and buying stations. In the peak production years of 1960 and 1961, average ore grades were much higher $\left(\sim 0.25 \% \mathrm{U}_{3} 0_{8}\right)$. Therefore, although only about half the 1979 tonnage was mined in those years, greater quantities of $\mathrm{U}_{3} \mathrm{O}_{8}$ were

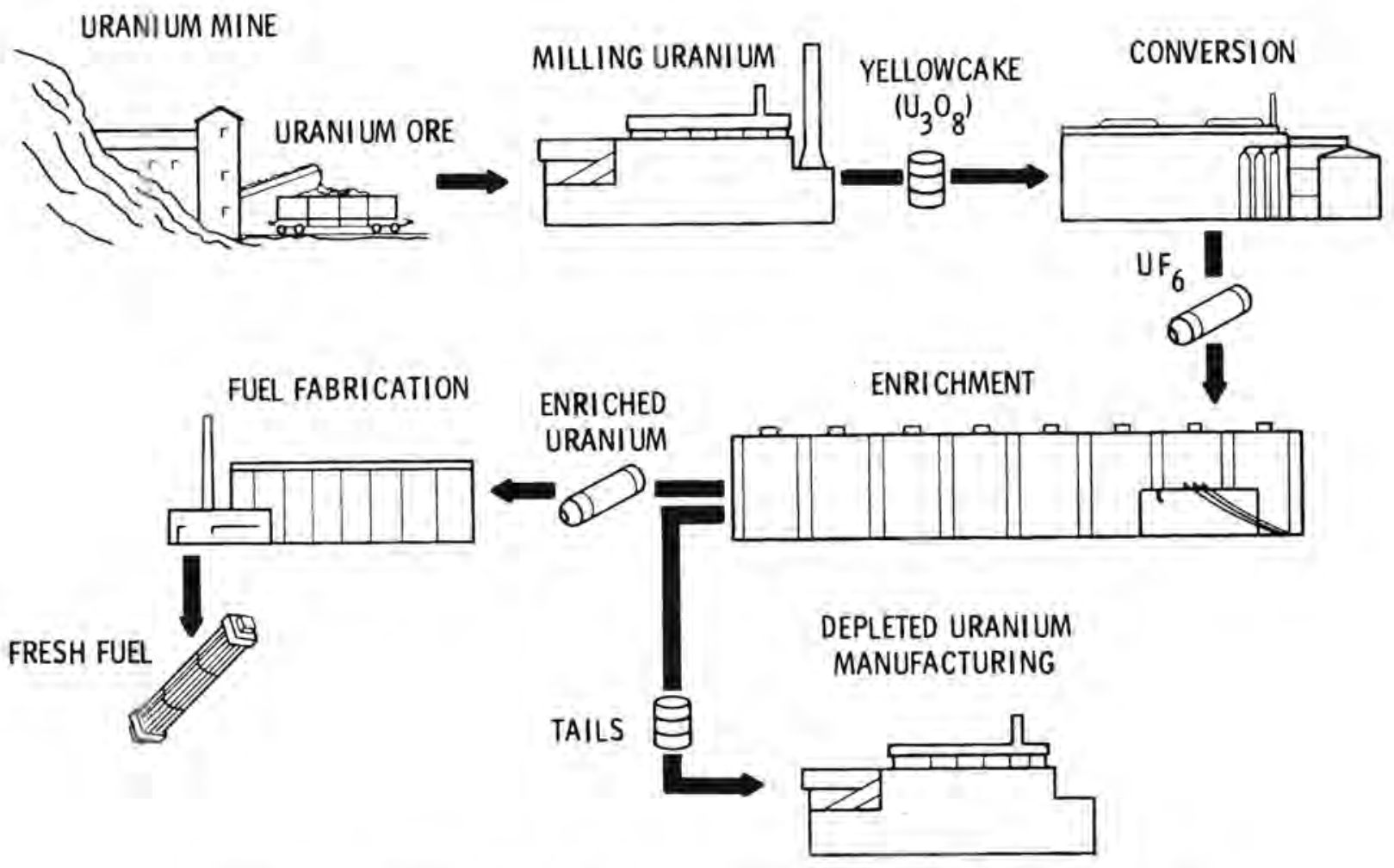

FIGURE 1. Front End of the Uranium Fuel Cycle (ERDA 1975) 
present (DOE 1980). The decrease in the $\mathrm{U}_{3} \mathrm{O}_{8}$ content of ore over the years has resulted in a need for greater quantities of mined ore to meet demands.

In the early years, most uranium ore was mined by underground methods. It was not until 1953 that open-pit mining started contributing significantly ( $25 \%$ ) to the total ore production. Production from open-pit mines continued to increase steadily until 1971, when it surpassed underground ore production. This trend is continuing (DOE 1980).

Table 1 presents a comparison of 1979 data for open-pit and underground mines. About five times as many underground mines as open-pit mines operated during 1979; however, the total production capacity of open-pit mines was approximately twice that of underground mines. Underground mining is more labor intensive than open-pit mining: it takes approximately two and a half times as many workers to mine a ton of ore by underground methods as by openpit methods.

Other mining methods include solution mining, the recovery of uranium from phosphoric acid (referred to in this document as uranium recovery), and heap leaching. In $1979,25 \%$ of the 20,700 tons $(18,770 \mathrm{t})$ of $\mathrm{U}_{3} \mathrm{O}_{8}$ was produced by these methods (DOE 1980).

Figure 2 shows the locations of the uranium resource regions of the United States. The Colorado Plateau and the Wyoming Basins have been and

\section{TABLE 1. 1979 Mining Data(a)}

\begin{tabular}{lccccc} 
& $\begin{array}{c}\text { Number of } \\
\text { Mines }\end{array}$ & $\begin{array}{c}\text { Tons of } \\
\text { Ore Mined }\end{array}$ & $\begin{array}{c}\text { Tons of U308 } \\
\text { in Mined Ore }(b)\end{array}$ & Miners \\
\cline { 2 - 2 } Open-Pit Mines & 62 & & $9.7 \times 10^{6}$ & 9400 & 2311 \\
Underground Mines & 300 & $5.4 \times 10^{6}$ & 6300 & 3064
\end{tabular}

(a) Source: DOE 1980.

(b) Calculated by multiplying tons of ore mined times average ore grade. 


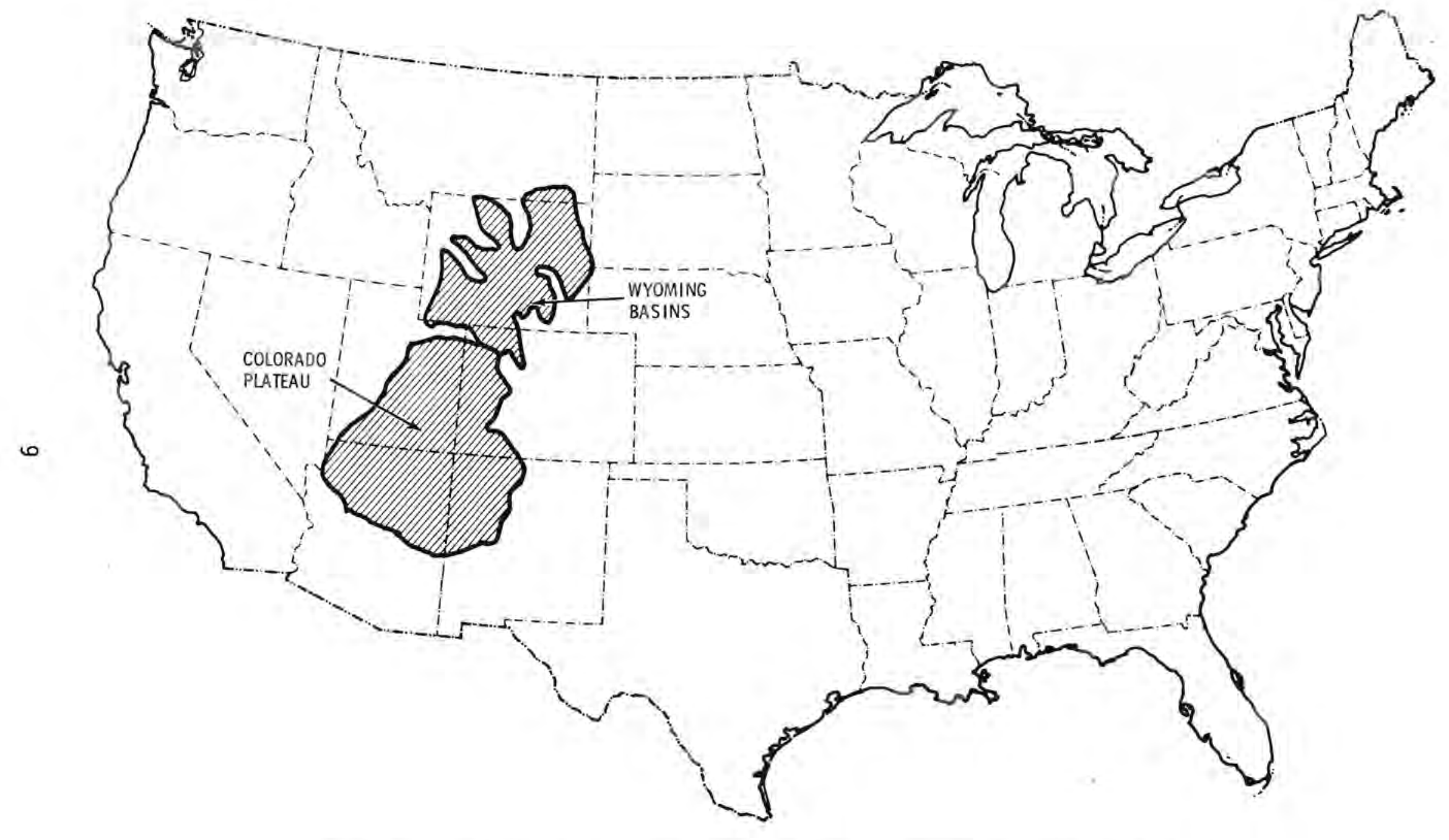
FIGURE 2. Uranium Resource Regions of the United States (derived from
DOE 1980) 
continue to be the major uranium-ore-producing areas. During 1979, $49 \%$ of the $\mathrm{U}_{3} \mathrm{O}_{8}$ produced from ore came from the Colorado Plateau and $28 \%$ from the Wyoming Basins (DOE 1980).

The processes described below are for open-pit and underground mining. Solution mining, uranium recovery operations, and heap-leaching processes are more closely related to uranium milling and will be described in a later section.

\section{Process Description}

The decision to mine by open-pit or underground methods is dependent on mining costs. These costs are influenced by such factors as the size, shape, grade, depth, and thickness of ore deposits.

Open-pit mining is used when ore deposits are near the surface and the overburden can be easily removed. It is feasible to depths of more than $500 \mathrm{ft}$ $(152 \mathrm{~m})$, but underground mining is usually the method of choice below $300 \mathrm{ft}$ $(91 \mathrm{~m})$. The first step in the process is to remove topsoil using tractor scrapers and to stockpile it for the later reclamation of the excavated areas. Next, overburden, which consists primarily of unconsolidated sandstone and mudstone, is removed using diesel-power shovels. The overburden is stockpiled for use as backfill for excavated pits. Ore pockets are then identified with Geiger counters, and scrapers remove waste in the immediate area of the ore. The exposed ore is blasted or loosened with rippers and loaded into dump trucks. The ore in each truck is assayed for uranium content by gamma-ray analysis at a probe tower and taken to nearby blending piles. Finally, frontend loaders load the blended ore into ore-hauling trucks for transport to the milling location.

Underground mining is preferred when the uranium ore lies at depths where the removal of overburden would be too costly. The size of ore bodies mined by underground methods is variable. The largest ore bodies may be as much as $0.5 \mathrm{mile}(0.8 \mathrm{~km}$ ) long, several hundred feet (up to $100 \mathrm{~m}$ ) wide, and from 5 to $100 \mathrm{ft}(1.5$ to $30 \mathrm{~m})$ thick. The first step in the underground mining process is the construction of a vertical shaft $(\mathrm{s})$ about $15 \mathrm{ft}(4.6 \mathrm{~m})$ in diameter to the depth of the ore body. The men and materials necessary for mining enter 
via the shaft and the mined ore is removed through it. Once the shaft is completed, two types of horizontal drifts are constructed outward from it beneath the ore zone: haulage drifts, which parallel the length of the ore body, and crosscut drifts, which run perpendicular to the haulage drifts to reach the extremities of the ore body. Ventilation holes (typically 3 to $6 \mathrm{ft}$ or 0.9 to $1.8 \mathrm{~m}$ in diameter) are bored at various locations from the surface down to the drifts. Ore bodies are entered from beneath, through vertical or inclined openings (raises) driven up from the drifts, to utilize gravity for ore handiing and for drainage of ground water from the ore body.

Once drifts and raises are complete, extraction or stoping of an ore body begins by one of several stoping methods, including open, room and pillar, and square set. The type of stoping method used depends on the stability of the earth and the size and shape of the ore deposit. Ore is loosened by drilling or blasting and then is moved to the raises by mechanical slushers. At the bottom of raises, the ore is pulled out of chutes into trains of ore cars. The trains move the ore to a shaft pocket where it is dumped into a slusher trench. From there, the ore is moved with a large slusher hoist and bucket to a loading pocket where it is measured to fill one ore skip with a typical capacity of 4 to 6 tons (3.6 to $5.4 \mathrm{t}$ ). Skips are then hoisted to the surface for distribution to stockpiles or to a mill.

\section{Radiological Exposures}

In open-pit uranium-ore mines, radiological exposures to workers are minimal. Airborne radioactivity is negligible because of the diluting effect of the atmosphere. The levels of external radiation to which open-pit workers are exposed are higher than background levels, particularly near ore deposits and ore-hauling trucks. One company reports an average annual external dose of 45 mrem for their open-pit workers (Miller and Scott 1980).

In underground mines, the primary radiological hazard is exposure to airborne radionuclides, especially the inhalation of airborne radon and shortlived radon daughters. Radon-222 is an inert noble gas that passes freely into and out of workers' lungs with minimal deposition in the respiratory system. Short-lived radon daughters $\left({ }^{218} \mathrm{Po},{ }^{214} \mathrm{~Pb},{ }^{214} \mathrm{Bi},{ }^{214} \mathrm{Po}\right)$ can 
enter the respiratory tract as single, unattached atoms or attached to dust particles. The single atoms (the unattached fraction) of radon daughters are considered more hazardous than those that are attached because they deposit preferentially in the upper passages of the respiratory tract. Alpha decay of inhaled radon daughters results in a radiation dose to the respiratory system about 20 times greater than that from the decay of radon (IAEA 1976). Because radon (a daughter of ${ }^{226} \mathrm{Ra}$ ) continuously emanates from the ore, ventilation air is needed to prevent the buildup of high concentrations of radon daughters. Significant increases in lung cancer noted among underground uranium miners have been shown to be the result of excessive exposure of the tracheobronchial epithelium to radon daughters (National Research Council 1980).

The inhalation of long-lived alpha emitters $\left({ }^{235} \mathrm{U},{ }^{234} \mathrm{U},{ }^{230} \mathrm{Th},{ }^{226} \mathrm{Ra}\right.$, $210 \mathrm{Po}$ ) is less of a concern than the inhalation of radon and its daughters. Underground mining activities such as drilling and blasting can produce increased ore dust levels; however, the concentrations of long-lived radionuclides in ore dust are usually maintained at levels below the maximum permissible limits as a result of forced ventilation.

Underground uranium miners are also exposed to external beta and gamma radiation emitted by ore bodies at levels that are highly dependent on the grade of the ore. One company reports an average annual external dose of 332 mrem for their underground miners (Miller and Scott 1980). Where high ore grades are mined, external exposures can approach the 5-rem/yr whole-body limit.

Milling

Uranium milling is a physical and chemical process that extracts the uranium from ore. The product is a semirefined uranium compound called yellowcake, which encompasses a variety of uranium compounds with different colors, chemical compositions, and solubilities in lung fluids. Yellowcake contains between $80 \%$ and $97 \%$ uranium, usually in the form of uranium oxide $\left(\mathrm{U}_{3} \mathrm{O}_{8}\right)$. The terms yellowcake and $\mathrm{U}_{3} \mathrm{O}_{8}$ are used interchangeably throughout the industry.

Uranium milling processes in the United States can be divided into two categories, conventional and unconventional. As of January 1, 1980, 21 
operating conventional mills accounted for approximately $90 \%$ of the $\mathrm{U}_{3} \mathrm{O}_{8}$ produced in 1979 (DOE 1980). The conventional mills are characteristically located near the mines in arid, isolated regions of the American West, as shown in Figure 3 . Of the approximately 18,730 tons $(16,990 \mathrm{t})$ of $\mathrm{U}_{3} \mathrm{O}_{8}$ produced in 1979, about $40 \%$ and $29 \%$ came from the states of New Mexico and Wyoming, respectively (DOE 1980).

Conventional mills are rated according to their ore-processing capacity (tons of ore processed per day or TPD). The largest conventional mill has a rated capacity of 7000 TPD, the smallest 450 TPD. The number of workers (operators and maintenance personnel) is generally less than 50 for a smallcapacity mill (<1000 TPD or <900 t/day), 50 to 100 for an intermediatecapacity mill (1000 to 3000 TPD or 900 to $2700 \mathrm{t} /$ day) and 100 to 250 for a large-capacity mill (3000 to 7000 TPD or 2700 to $6300 \mathrm{t} /$ day).

The three major unconventional milling processes used in the United States are solution (in-situ) mining, uranium recovery operations, and heap leaching. These processes accounted for approximately $10 \%$ of the total yellowcake production in 1979. Solution mining produced approximately $6 \%$ of the total, uranium recovery approximately $3 \%$, and heap leaching approximately $1 \%$. In addition, uranium can be recovered as a by-product of copper and beryllium milling. These processes contributed less than $1 \%$ of the total yellowcake production in 1979 (DOE 1980).

Figure 3 shows the locations of unconventional milling operations in the United States. As of January 1, 1980, 10 solution mines were operating, primarily in southern Texas; four uranium recovery operations were located in Florida and Louisiana; and four heap-leaching operations were scattered throughout the western United States (DOE 1980). The yellowcake production capacity of unconventional operations ranges from 125 to 500 tons (113 to $454 \mathrm{t}$ ) per year (in the range of small-capacity conventional mills). The number of workers (operators and maintenance personnel) dealing with uranium milling is generally less than 50 per operation. In 1979, there were approximately 2100 workers at conventional mills (DOE 1980) and about 600 workers at unconventional mills. These employment figures include only maintenance and production workers. Office and supervisory personnel are not included, as they generally do not have a potential for uranium exposure. 


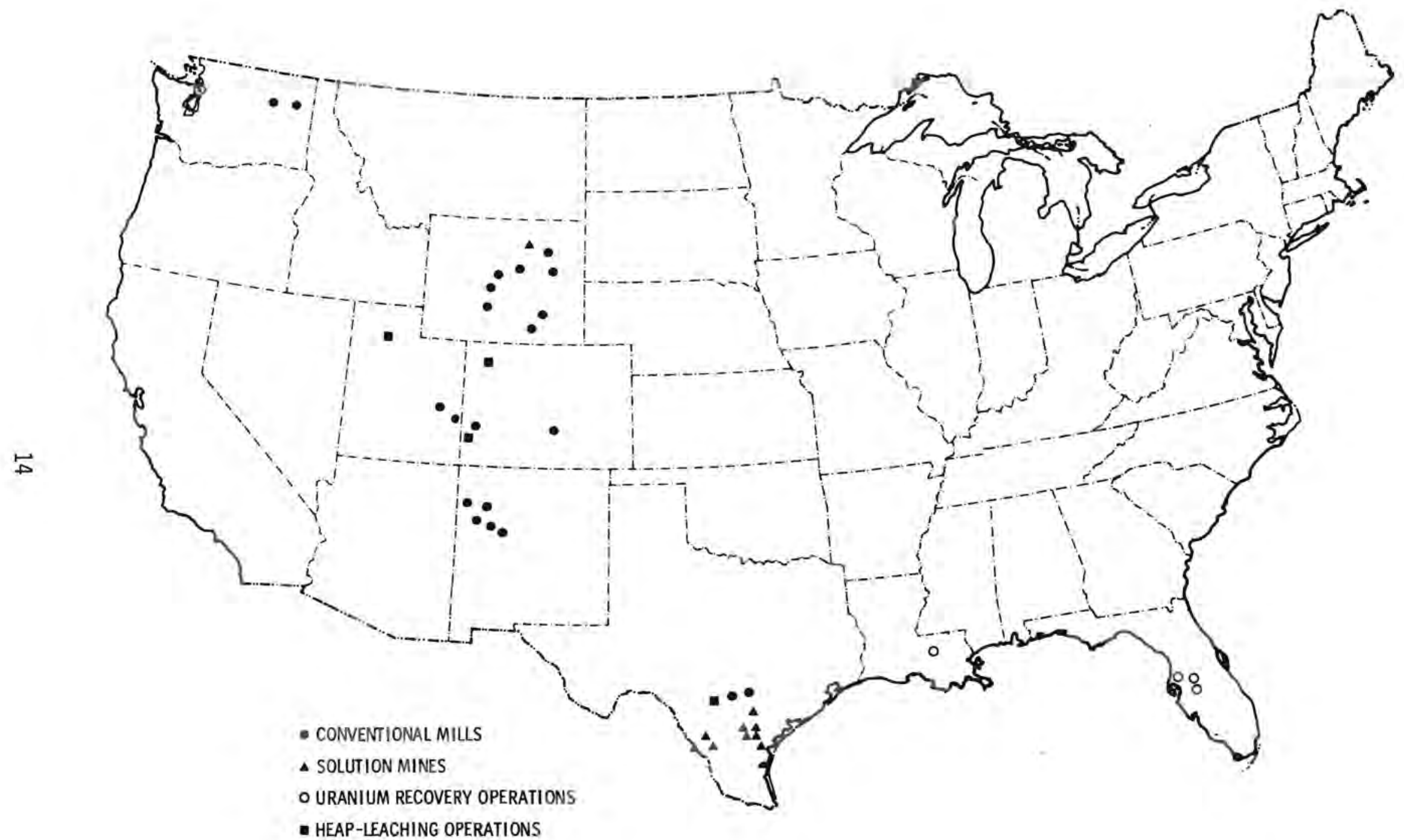

FIGURE 3. Uranium Mills in the United States Operating as of $1 / 1 / 80$ (derived from DOE 1980) 


\section{Process Descriptions}

The four major phases in the conventional milling process are ore handling and preparation, extraction, concentration and purification, and precipitation. Figure 4 is a flow-diagram of the basic process. Ore handling and preparation is a physical step that comprises the blending, crushing, and grinding of the ore in preparation for the extraction phase. In the extraction phase, uranium is chemically leached from the ore by either an acid or an alkaline solution, depending on the lime content of the ore. Seventeen of the 21 conventional mills have ores with a low enough lime content to use an acid leach process. The other four mills, which handle ores with a lime content greater than about $12 \%$, use an alkaline leach process.

In the next step, one of several chemical methods is used to concentrate and purify the feed solution from the extraction phase. The acid leach mills use one of three methods, depending on ore characteristics: solvent extraction is used by 10 mills, ion exchange by 3 mills, and Eluex by 4 mills. In the solvent extraction process, uranium in the feed solution is extracted into an organic phase using an organic solvent and is subsequently stripped into an aqueous phase using an ammonium sulfate solution or other appropriate compound. The ion exchange process involves passing the feed solution through a resin column where uranium adsorbs on the resin and then is selectively removed by passing an elution or stripping solution through the column. The Eluex process is a combination of the ion exchange and solvent extraction processes. The feed solution from an alkaline leach extraction process generally requires no concentration and purification, as this process extracts uranium more selectively than the acid leach process. One alkaline leach mill, however, uses an ion exchange type of process (resin-in-pulp) to concentrate and purify the feed solution.

The final phase of the conventional milling process is the precipitation of uranium, usually in the form of ammonium diuranate (ADU), written chemically as $\left(\mathrm{NH}_{4}\right)_{2} \mathrm{U}_{2} \mathrm{O}_{7}$. Acid leach mills precipitate the uranium product by the addition of 1 ime and ammonia in a two-stage process, the addition of ammonia, or the addition of hydrogen peroxide, depending on the impurities in the feed solution. The principal method of precipitation in alkaline leach mills is the 


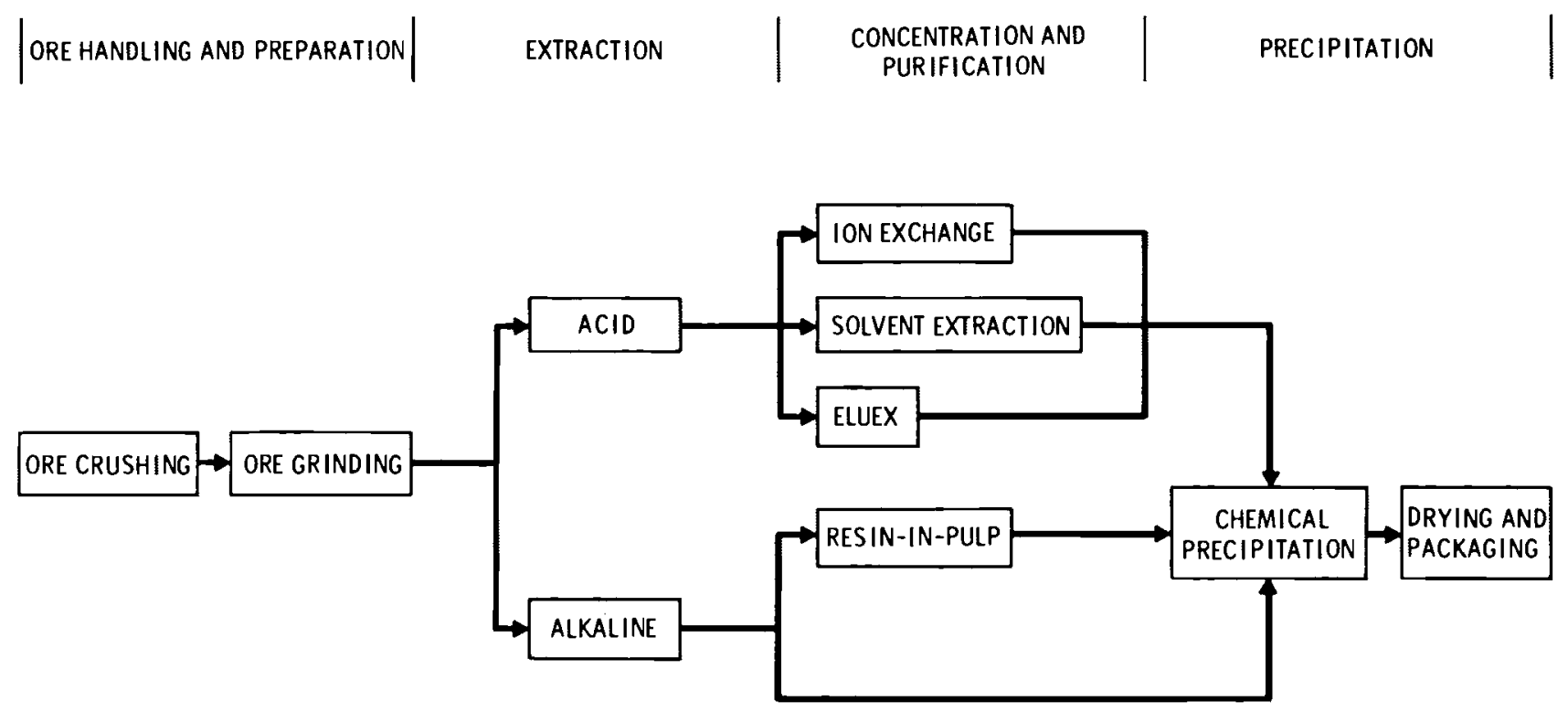

FIGURE 4. Flow Diagram of Basic Conventional Milling Steps 
addition of caustic soda (sodium hydroxide). The ADU product is then dewatered, filtered, washed, dried, and packaged. Mills that dry their product at relatively high temperatures $\left(370^{\circ}\right.$ to $\left.538^{\circ} \mathrm{C}\right)$ obtain a greenishblack powder high in uranium oxide $\left(\mathrm{U}_{3} \mathrm{O}_{8}\right)$ content. Drying at lower temperatures $\left(100^{\circ}\right.$ to $\left.150^{\circ} \mathrm{C}\right)$ results in a yellow-colored product high in ADU content.

None of the three major unconventional milling processes has a dry-ore handling and preparation phase. The extraction phases of unconventional processes also differ from those of conventional milling processes. At a solution-mining operation, uranium is extracted from ore by injecting a leaching solution into an underground ore body and then pumping the uraniumenriched solution to the surface. In uranium recovery operations, the phosphoric acid produced at commercial phosphoric acid plants is diverted, uranium is extracted from the acid solution, and the acid is returned to the phosphoric acid plant. The extraction phase in a heap-leaching operation involves percolating a leach solution through a low-grade ore pile or tailings pile and collecting the uranium-enriched solution as runoff. The uranium-enriched solutions of the unconventional processes then must pass through a concentration and purification phase and a precipitation phase similar to those of the conventional milling process.

\section{Radiological Exposures}

The greatest potential for occupational radiation exposure in uranium milling is the inhalation of airborne uranium compounds. Of primary concern is inhalation of ore dust in the crushing area and yellowcake dust in the drying and packaging area of conventional operations. The hazard is most acute during maintenance activities. Other steps in the milling process (extraction, concentration and purification, precipitation) present minimal inhalation hazard because the uranium is in a liquid solution during normal operations. Unconventional milling operations include no ore-crushing phase, and inhalation of yellowcake dust in the drying and packaging area is the major concern.

Workers of interest at uranium mills include operators and maintenance personnel. In 1979, there were 1165 operators and 951 maintenance personne 1 
at conventional mills (DOE 1980). Operators in the crushing area and in the yellowcake drying and packaging area each account for approximately $10 \%$ to $20 \%$ of the mill operators. Some mills rotate their operators among different assignments semiannually or annually, with the result that all operators work at some time in the crushing and drying and packaging areas. Maintenance personnel, who work throughout the mill, have the potential for exposure to a variety of uranium compounds (ore dust, $\mathrm{ADU}, \mathrm{U}_{3} \mathrm{O}_{8}$ ).

The hazard associated with the inhalation of ore dust is the presence of long-lived alpha emitters $\left({ }^{238} \mathrm{U},{ }^{234} \mathrm{U},{ }^{230} \mathrm{Th},{ }^{226} \mathrm{Ra}\right.$, and $\left.{ }^{210} \mathrm{Po}\right)$. Because these nuclides are mostly insoluble in lung fluids, they remain in the body for long periods.

The relative hazard of yellowcake inhalation in the drying and packaging area is dependent on the temperature at which the ADU product is dried. The bright yellow compound, high in ADU, produced at mills that dry their product at a relatively low temperature $\left(100^{\circ}\right.$ to $\left.150^{\circ} \mathrm{C}\right)$ is highly soluble in lung fluids. Ammonium diuranate can accumulate in different parts of the body (e.g., bone), resulting in an internal radiation dose; however, of primary concern is its chemical toxicity to kidney tissue. The greenish-black uranium oxide compound $\left(\mathrm{U}_{3} \mathrm{O}_{8}\right)$ produced where drying is done at relatively high temperatures $\left(370^{\circ}\right.$ to $\left.538^{\circ} \mathrm{C}\right)$ is mostly insoluble in lung fluids. This form of uranium concentrates in the lung, delivering an internal radiation dose. Kalkwarf (1979), Eidson and Mewhinney (1978 and 1980), and Cooke and Holt (1974) have attempted to determine the relative solubility of yellowcake compounds in simulated lung fluid.

Annual external whole-body doses to mill workers are generally less than 2 rem. For 1975, doses at NRC-licensed mills averaged 0.41 rem, with only three of the 437 monitored workers receiving a dose in excess of 2 rem (Cool 1978).

\section{Conversion}

Conversion is a chemical process during which yellowcake is purified and converted to volatile uranium hexafluoride $\left(\mathrm{UF}_{6}\right)$. Two commercial conversion facilities exist in the United States today, one located in Illinois and the 
other in 0klahoma. The total production capacity of these facilities is approximately 18,000 tons $(16,300 \mathrm{t})$ of uranium per year. The two facilities employ a total of approximately 350 workers in uranium process areas.

\section{Process Descriptions}

The uranium industry currently uses two processes for the purification and conversion of yellowcake to $\mathrm{UF}_{6}$ : fluorination-fractional distillation, and solvent extraction-fluorination. These processes are commonly referred to as the dry and wet processes, respectively. The major steps in each process are sampling, feed preparation, conversion, and purification. The primary difference between the two is that in the dry process, the conversion to $\mathrm{UF}_{6}$ precedes purification, while in the wet process, conversion follows purification. Figure 5 is a diagram of the two processes.

The sampling phase of both processes consists of emptying the 55-gal (208- $\ell$ ) drums of yellowcake received from the mills into a hopper, blending the contents, collecting a sample, and refilling the drums. The sample is analyzed for chemical and physical characteristics that may affect the process and to determine total uranium content. Sampling is done in an area separate from the remainder of the process area for dust control purposes.

The feed preparation phase is initiated by empyting yellowcake from drums into the process. In the dry process, feed preparation requires several steps to produce a material with the proper chemical and physical characteristics. The initial step is calcination, which dries the yellowcake and converts many of the uranium compounds to uranium oxide $\left(\mathrm{U}_{3} \mathrm{O}_{8}\right)$. This step is followed by crushing and blending to provide a uniform mixture before the feed is remoistened, formed into pellets, dried, and crushed into a homogeneous $\mathrm{U}_{3} \mathrm{O}_{8}$ powder. In the wet process, yellowcake is digested in large tanks of nitric acid for 8 hours. The resulting prepared feed is uranyl nitrate solution $\left(\mathrm{UO}_{2}\left(\mathrm{NO}_{3}\right)_{2}\right)$.

As shown in Figure 5 , the next step in the dry process is conversion to $\mathrm{UF}_{6}$. The $\mathrm{U}_{3} \mathrm{O}_{8}$ powder is first processed with hydrogen gas (from cracked ammonia) through a fluidized-bed reductor for intermediate conversion to uranium dioxide powder $\left(\mathrm{UO}_{2}\right)$. Further conversion to uranium tetrafluoride 


\begin{tabular}{|c|c|c|c|c|c|c|c|}
\hline & SAMPLING & $\begin{array}{c}\text { FEED } \\
\text { PREPARATION }\end{array}$ & CONVERSION & & PURI & IFICATION & \\
\hline $\begin{array}{l}\text { DRY } \\
\text { PROCESS }\end{array}$ & $\begin{array}{l}\text { YELLOWCAKE } \\
\text { BLENDING \& } \\
\text { SAMPLING }\end{array}$ & CALCINATION & 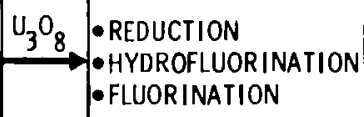 & $\frac{\mathrm{UF}_{6}}{\text { GAS }}$ & $\begin{array}{c}\text { DISTILLATION } \\
\text { AND } \\
\text { CONDENSATION }\end{array}$ & $\frac{\mathrm{UF}_{6}}{\mathrm{LIQUID}}$ & PACKAGING \\
\hline
\end{tabular}

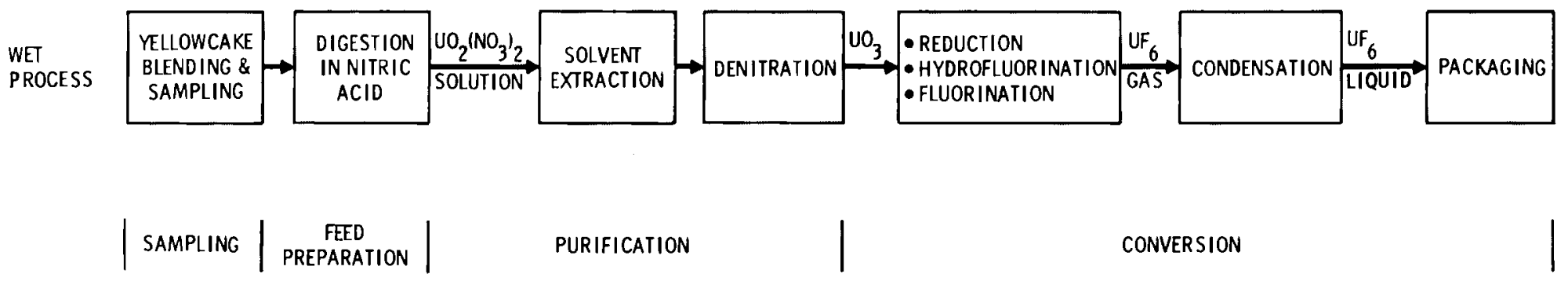

\section{FIGURE 5. Flow Diagram of Conversion Processes}


$\left(\mathrm{UF}_{4}\right)$ is accomplished in a series of fluidized-bed hydrofluorinators into which $\mathrm{UO}_{2}$ and hydrogen fluoride (HF) gas are introduced. Final conversion takes place in a fluidized-bed fluorinator, where the $\mathrm{UF}_{4}$ powder and fluorine $\left(F_{2}\right)$ gas are combined to form gaseous $U_{6}$. The $U_{6}$ is purified in the dry process in a series of fractional distillation columns. Here, impurities including molybdenum and vanadium are boiled out while others (including uranium daughters) are collected as ash at the base of the columns. The product is $99.99 \% \mathrm{UF}_{6}$.

Following the feed preparation phase, the next step in the wet process is purification, as shown in Figure 5. The uranyl nitrate solution from the feed preparation phase is purified by a solvent extraction process. The uraniumloaded solvent is then scrubbed with acidified water to remove residual impurities, and the uranyl nitrate is re-extracted into the aqueous phase. The solution is then concentrated in a two-phase evaporation system, producing uranyl nitrate which is denitrated to uranium trioxide $\left(\mathrm{UO}_{3}\right)$ powder in a stirred trough. Finally, the $\mathrm{UO}_{3}$ powder is pulverized in a hammer mill. The conversion of $\mathrm{UO}_{3}$ to $\mathrm{UF}_{6}$ is accomplished using a technique similar to the conversion phase of the dry process.

Following the conversion to $\mathrm{UF}_{6}$ in both the dry and wet processes, the gaseous $\mathrm{UF}_{6}$ is condensed and drained into stee 1 cylinders. When full, the cylinders are placed in steam chests where the $\mathrm{UF}_{6}$ is maintained as a liquid and homogenized by rotation of the cylinders. After the $\mathrm{UF}_{6}$ is sampled, the cylinders are cooled to solidify the $\mathrm{UF}_{6}$ into a white crystalline material. The cylinders are then weighed and placed in an outdoor storage yard to await shipment.

\section{Radiological Exposures}

As in uranium mills, the greatest potential for occupational radiation exposure in conversion facilities is the inhalation of airborne uranium compounds. Inhalation is most likely to occur during the emptying and refilling of yellowcake drums in the sampling area, the removal of ash waste following the purification phase, and maintenance activities throughout the facilities. Inhalation of uranium daughters would be of concern during the removal of ash 
waste. Maintenance personnel could be exposed to all the uranium compounds found in the facility, including yellowcake, uranium daughters, $\mathrm{UF}_{4}, \mathrm{UO}_{2}, \mathrm{UO}_{3}$, and uranyl fluoride $\left(U_{2} F_{2}\right)$. Exposure to $U_{6}$ is not likely because $U_{6}$ reacts with moisture in the air and forms $\mathrm{UO}_{2} \mathrm{~F}_{2}$ and $\mathrm{HF}$.

An approximate breakdown of the conversion work force is $60 \%$ production and $40 \%$ maintenance. Less than $10 \%$ of the production force works in the sampling plant, where there is a potential for inhaling yellowcake from the emptying of drums. Because of the nature of maintenance activities, maintenance workers have the potential for exposure to a variety of uranium compounds.

Uranyl fluoride, like ADU, is highly soluble in lung fluids and, if inhaled, would be distributed to other body organs, delivering an internal radiation dose. Chemical toxicity to kidney tissues would be the major concern, however, as soluble uranium compounds are readily eliminated from the body. Uranium tetrafluoride and uranium dioxide, two intermediate compounds formed in the conversion process, are relatively insoluble in lung fluids and would concentrate in the lung, delivering an internal radiation dose.

Annual external whole-body doses to conversion workers are we 11 below the 5-rem/yr limit. In 1975, doses at conversion facilities averaged 0.22 rem, with no doses exceeding 2 rem (Cool 1978).

\section{Enrichment}

Enrichment is a gaseous diffusion process that increases the ${ }^{235} \mathrm{U}$ concentration of the $\mathrm{UF}_{6}$ feed material by selectively removing ${ }^{238} \mathrm{U}$. Uranium is enriched for both commercial and government use at three government-owned and contractor-operated gaseous diffusion enrichment facilities in Tennessee, Kentucky, and Ohio. In addition to enrichment operations, activities at the three sites have included the conversion of $U_{3}$ to $U_{6}, U F_{6}$ to $U F_{4}$, and $U_{4}$ to metal, and decontamination and maintenance of diffusion equipment.

All three plants receive natural UF $_{6}{ }^{*}$ The Kentucky plant also receives depleted $\mathrm{UF}_{6}$ from the other two plants and returns to them enriched $\mathrm{UF}_{6}$ in the range of $0.9 \%$ to $2.0 \%{ }^{235} \mathrm{U}$. The end product of the Tennessee plant is up to $5 \%$ enriched $U_{6}$ for commercial use. The Ohio plant produces both $4 \%$ 
$\mathrm{UF}_{6}$ for commercial use and $>90 \%$ enriched $\mathrm{UF}_{6}$ for military and research uses. A11 three plants produce tailings of $0.2 \%{ }^{235} \mathrm{U}$.

Although each enrichment plant employs thousands of workers, under normal working conditions only about $19 \%$ of the work force has a potential for exposure to uranium.

\section{Process Description}

The enrichment facility receives $U_{6}$ in solid form in large stee 1 cylinders (see Figure 6). After being weighed and sampled for uranium analysis, the $U_{6}$ is heated and loaded into the enrichment cascade as a gas. The enrichment cascade is a series of many stages of diffusion equipment. Each stage consists of a converter containing the diffusion barrier and a compressor that pressurizes the enriched stream from the previous stage, creating a pressure differential across the barrier in the next converter. This pressure differential enhances the diffusion of $U F_{6}$ across the barrier. Although the $\mathrm{UF}_{6}$ is pressurized with respect to the barrier, it is still at much less than atmospheric pressure. The $U_{6}$ is enriched in ${ }^{235} U$ content because the ${ }^{235} U$ diffuses through the cascade barrier more rapidly than ${ }^{238} U$. Because
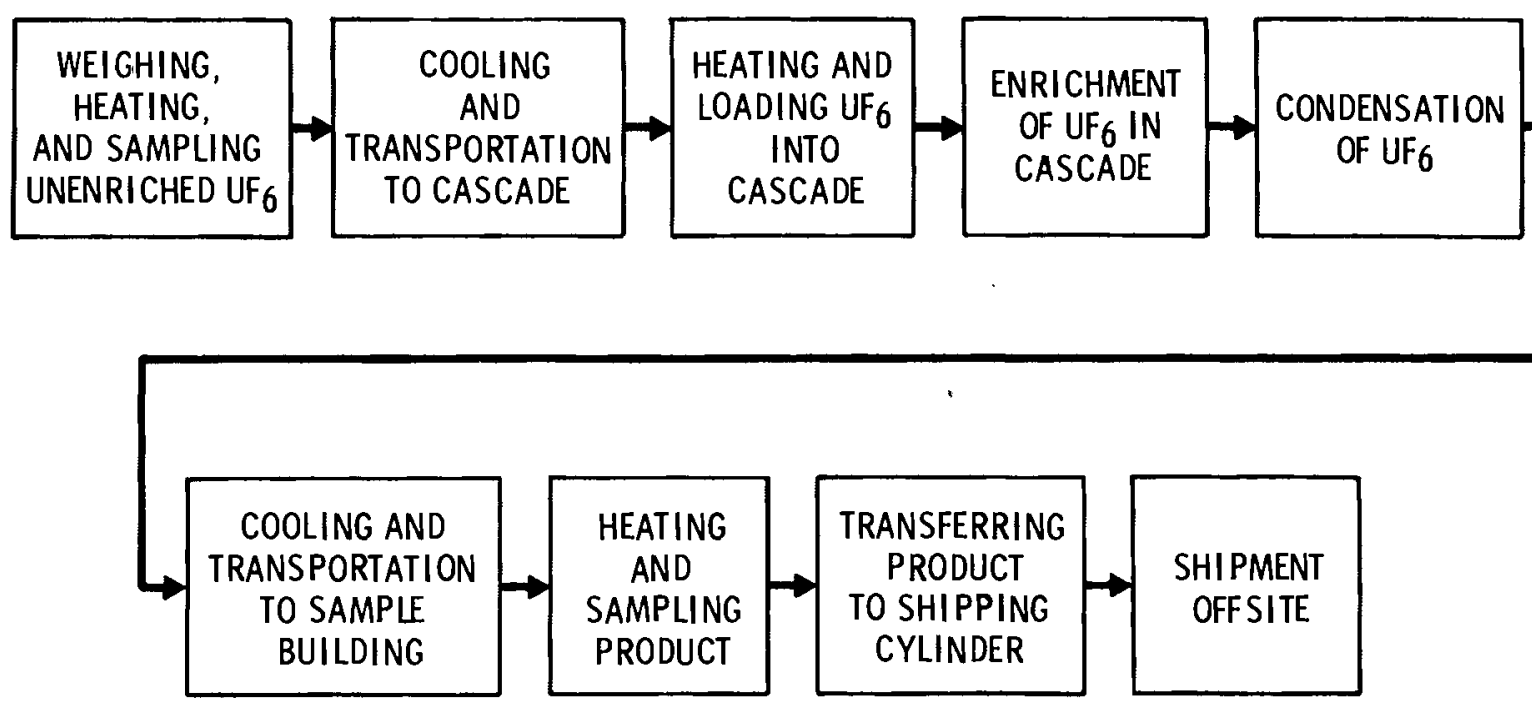

FIGURE 6. Flow Diagram of Enrichment Process 
the difference in diffusion rates for ${ }^{235} U$ and ${ }^{238} U$ is very sma11, many diffusion stages are required to achieve the desired enrichment. In total, the diffusion cascades cover many acres and are housed in large buildings.

When the proper enrichment is reached, the $U_{6}$ is drained as a liquid into large steel cylinders. Each large cylinder is drained into smaller shipping cylinders, which are weighed and sampled before shipment offsite.

When maintenance is required, cascade operations continue while the equipment requiring maintenance is valved off from the remainder of the system. The equipment is then evacuated and purged with air to remove UF $_{6}$ before being disconnected. The openings are sealed with plastic and the equipment is removed for decontamination and repair.

\section{Radiological Exposures}

During normal operations, the cascade buildings are unoccupied except for control room operators. Because the cascade is a closed process, there are no routine concentrations of uranium in the building work areas. The cascade operators routinely collect samples of $\mathrm{UF}_{6}$ by attaching a sample bulb or other apparatus to a sampling manifold. At this time, operators may be exposed to $U_{6}$ through an inadvertent release. Operators may also be exposed during connection and disconnection of cylinders for $U_{6}$ load-in and load-out and during cylinder sampling.

Despite the evacuation and purge in connection with maintenance activities, it is not uncommon for $U_{6}$ or $U_{2} \mathrm{~F}_{2}$ to be present when the equipment is opened. Maintenance workers are also near potentially contaminated surfaces during manual decontamination. In addition, cavities (such as valves) within equipment being dismantled may contain trapped $\mathrm{UF}_{6}$.

\section{Fuel Fabrication}

Fuel fabrication is a physical and chemical process that converts enriched $\mathrm{UF}_{6}$ to uranium dioxide $\left(\mathrm{UO}_{2}\right)$ powder and then mechanically forms the $\mathrm{UO}_{2}$ into pellets, which are loaded into fuel assemblies. The current fuel fabrication industry in the United States consists of seven facilities that perform all or a portion of the fabrication processes necessary to produce finished fuel assemblies. These facilities are located in Pennsylvania, Connecticut, 
Virginia, North Carolina, South Carolina, Missouri, and Washington State. Three facilities have the capability to accept enriched $U_{6}$ as feed and produce finished fuel assemblies, while two carry the process only as far as $\mathrm{UO}_{2}$ powder or pellet production. Two facilities complete the process by accepting $\mathrm{UO}_{2}$ powder or pellets and producing finished assemblies.

At the fuel fabrication facilities visited, production capacities range from 330 to 880 tons of uranium per year (299 to $798 \mathrm{t} / \mathrm{yr}$ ). The industry has approximately 1400 production and maintenance workers.

\section{Process Description}

The three basic phases of fuel fabrication are the production of $\mathrm{UO}_{2}$ powder, the production of sintered pellets, and final fuel assembly. Figure 7 is a diagram of the three phases. The following process description is for a typical fuel fabrication facility that converts $U_{6}$ to fuel assemblies.

In the production of the $\mathrm{UO}_{2}$ powder, the solid $\mathrm{UF}_{6}$ feed material is vaporized in an enclosed system for loading into the process. Next, the gaseous $U_{6}$ is piped to a hydrolyzation column where it reacts with water spray to form uranyl fluoride $\left(\mathrm{UO}_{2} \mathrm{~F}_{2}\right)$ and hydrofluoric acid $(\mathrm{HF})$. The uranyl fluoride is then reacted with ammonium hydroxide to form ammonium diuranate (ADU) precipitate and water. The ADU is dried and then calcined in a gas-fired rotary calciner under a hydrogen atmosphere to produce $\mathrm{UO}_{2}$. The $\mathrm{UO}_{2}$ is pulverized and transported by conveyor or in plastic containers to the pellet production area.

To produce sintered pellets, a binder material is mixed with the $\mathrm{UO}_{2}$ powder. The mixture is fed into a slug press that produces nickel-sized $\mathrm{UO}_{2}$ slugs. These slugs are granulated and fed to an enclosed pellet press that produces green (unsintered) pellets. The pellets are then sintered in a hydrogen atmosphere to make them denser, ground (wet or dry) to the proper dimensions, and inspected.

For fuel assembly, the inspected $\mathrm{UO}_{2}$ pellets are taken to the pinloading area where they are mechanically fed into prepared fuel pins. Once filled, each pin is sealed with an end cap, wiped clean, checked for contamination, and removed from the controlled area. After the end caps are welded, 


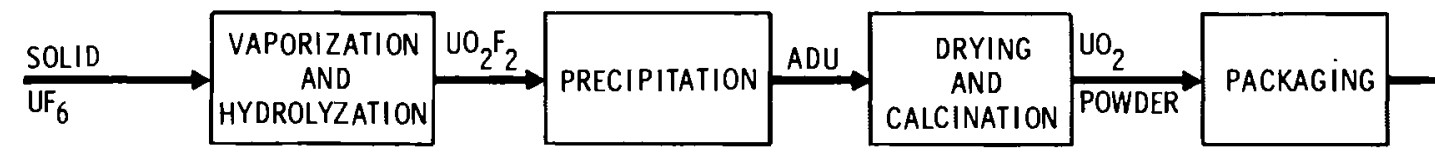

PRODUCTION

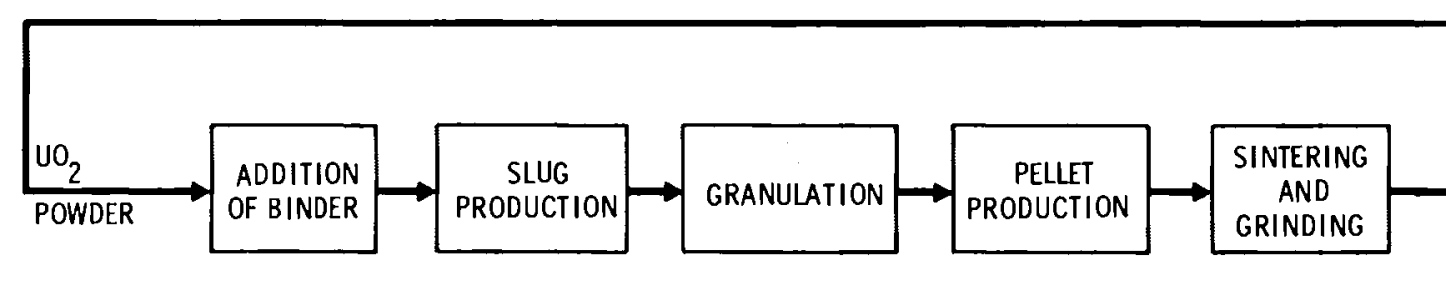

FUEL

ASSEMBLY

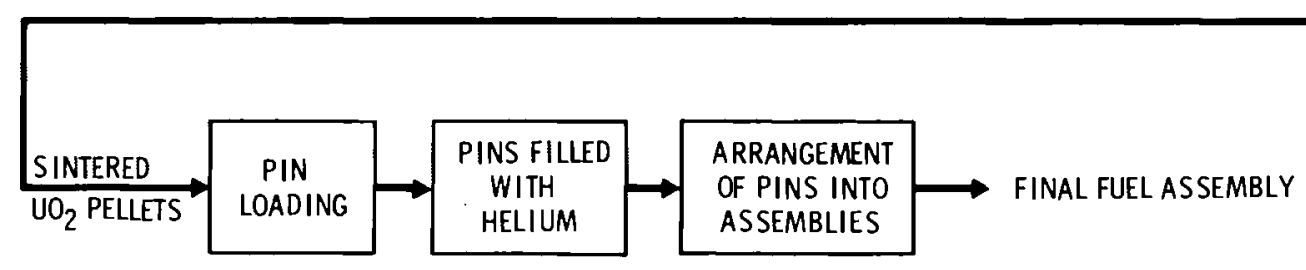

FIGURE 7. Flow Diagram of Fuel Fabrication Process 
the pins are evacuated through a laser-produced hole in the end cap and filled with helium gas. The hole is welded shut and the pins are processed through a series of cleaning and testing (quality assurance) steps. Acceptable pins are assembled into fuel assemblies, which are inspected and placed in storage to await shipment.

\section{$\underline{\text { Radiological Exposures }}$}

The major part of the fuel fabrication process (powder and pellet production and the pin-loading step of the fuel assembly phase) is carried out in a large open area that is controlled because of the potential for airborne contamination. The inhalation of $\mathrm{UF}_{6}, \mathrm{UO}_{2} \mathrm{~F}_{2}$, and $\mathrm{ADU}$ are possible in the production of $\mathrm{UO}_{2}$. A significant portion of the fuel fabrication process consists of powder-handling operations involving insoluble uranium compounds (primarily $\mathrm{UO}_{2}$ ). Therefore, inhalation exposures are a major concern. Areas of potentially high uranium air concentrations in the powder production phase are the conveyor system, $\mathrm{UO}_{2}$ packaging and unpackaging areas, and inspection points. In the pellet production phase, the powder-sampling area and the pellet press are also areas of high potential air concentrations. The extensive quality control inspections required for final fuel assemblies result in average annual whole-body external exposures on the order of $500 \mathrm{mrem}$, with maximum exposures as high as 2 rem.

Al1 production and maintenance personnel working in the controlled area are in an area of potentially high airborne uranium levels; therefore, inhalation hazards are the major concern. For workers in the uncontrolled area, external radiation is the major concern.

\section{OTHER URANIUM FACILITIES}

In addition to the current commercial uranium industry, two other types of uranium facilities need to be considered: inactive facilities (Manhattan Project facilities and closed commercial facilities) and currently operating noncommercial facilities such as DOE facilities. A discussion of such facilities is presented in this section. 
Inactive Facilities

A review of inactive facilities is important because excessive occupational exposures to uranium are likely to have occurred in the early industry when many of these facilities were operating. Therefore, there may be occupationally exposed individuals of interest for health-related studies.

Manhattan Project facilities were discussed in the introduction. Since most of these facilities have been closed for many years and since work during their operation was classified, reconstruction of working conditions and resulting occupational exposures would be very difficult. It is beyond the scope of this project to characterize the processes and radiological protection practices used at these plants during the Manhattan Project.

Inactive commercial facilities include 23 milling sites (Goldsmith 1976) and approximately 12 fuel fabrication facilities. Since these facilities are closed, a site visit approach to gather information on processes and potential high-exposure areas is not possible. Any available data on worker exposures from these facilities could be reviewed in an effort to determine whether adequate data is available for meaningful health-related studies.

Noncommercial Facilities

In addition to inactive facilities, there are approximately 20 operating noncommercial facilities that handle uranium. These include about 12 DOE facilities that are involved in work such as weapons testing, fabrication of nuclear material components, reprocessing of nuclear fuels, design and construction of nuclear test reactors, nuclear waste technology, and production of uranium metal. Approximately eight private facilities are involved in fabrication of special nuclear fuel types, uranium scrap projects, and handling of depleted uranium compounds.

An in-depth characterization of these facilities, like that done for the commercial uranium industry, will not be performed. The Registry could, however, identify worker populations that would be good candidates for the health-related studies. To date, four such facilities have been reviewed. 


\section{REGULATION OF THE COMMERCIAL URANIUM INDUSTRY}

This section provides a discussion of regulation of the uranium industry. It includes a historical review of regulatory agencies and procedures for each phase of the industry, from mining through fuel fabrication. In addition, current regulatory agencies and procedures are reviewed. Only regulations relating to occupational radiation exposures are discussed. This regulatory review will indicate the types of exposure evaluation records that have been and are now being kept on uranium workers and the responsibility for maintaining the records. This information will be valuable in the establishment of studies of worker health in this industry.

\section{MINING}

The measurement of radon daughters in underground mines began around 1950 . The Occupational Health Field Station of the U.S. Public Health Service in Salt Lake City, Utah, has records of many radon-daughter measurements made in mines between 1950 and 1960. The records comprise such items as the mine name and location, the identity of personnel working underground at the time of the survey, the location of sampled areas, and the concentration of radon daughters in working levels (WL). (a) State agencies and mining companies began monitoring radon daughters in underground mines in about 1960.

The first standard for radon daughters of $1 \mathrm{WL}$ was recommended by the U.S. Public Health Service in 1959 and by the American Standards Association, Inc., and the U.S. Atomic Energy Commission (AEC) in 1960. (b) Since the states were historically responsible for mine inspection, they adopted regulations similar to the recommended standard. The degree of enforcement in the five western

(a) A working level is equivalent to any combination of radon daughters in 1 liter of air that will result in the emission of $1.3 \times 10^{5} \mathrm{MeV}$ of alpha energy in the ir complete decay through $214 \mathrm{Po}$. This potential alpha energy will occur when $100 \mathrm{pC} i$ of $222 \mathrm{Rn}$ in 1 liter of air is in equilibrium with its daughter products.

(b) Historical reviews of regulation in the uranium underground mining industry can be found in a report of the Federal Radiation Council (1967) and in the proceedings of an IAEA panel (MCGinley 1975). 
states that mined uranium varied; however, the standard was effective in reducing average industry-wide WL values from 7 WL in 1957 to 2.1 WL in 1966.

In 1959, the Federal Radiation Council (FRC) was formed by an act of Congress (Public Law 86-373) to provide "guidance for all Federal agencies in the formulation of radiation standards and in the establishment and execution of programs in co-operation with states." In September 1967, FRC published the recommendation that no miner be exposed to more than 6 working level months $(W L M)^{(a)}$ in any period of 3 consecutive months or to no more than 12 WLM in any period of 12 consecutive months. In addition, individual exposure records were to be established and maintained. Prior to 1967, time-weighted evaluation of exposures had not been a generally adopted regulatory procedure. Instead, state regulations and the recommendations of the American Standards Association, Inc., were based on a certain maximum concentration of radon daughters. This maximum had to be exceeded before worker access to the radiation area was restricted. A more conservative standard ( 0.3 WL or 4 WLM annually) was proposed by the Labor Department just prior to the publication of FRC's 1967 report. As a result of the debate that followed on reducing the exposure limit, FRC recommended and adopted an annual exposure standard of 4 WLM as of July 1, 1971. This standard remains in effect in the United States today.

The Mining Enforcement and Safety Administration (MESA) of the Department of the Interior was responsible for enforcing mining regulations from the early 1970s until 1978. Mine inspection data taken by MESA in 1977 (U.S. Environmental Protection Agency (EPA) 1977) showed an average of 0.51 WL in underground uranium mines, a level that compares favorably with an average of 2.1 WL in 1966. Basic radiation protection standards with which mines must comply can be found in Title 30, Part 57 of the Code of Federal Regulations (30 CFR 57), which is updated annually.

The Federal Mine Safety and Health Act of 1977 (Public Law 93-173), effective March 9, 1978, provides the current health and safety standards for

(a) A working level month is defined as the exposure to a concentration of one WL for a period of $170 \mathrm{~h}$. The unit is used as a measure of cumulative or time-integrated exposure for an individual inhaling radon daughters. 
the mining industry. As part of the Act, the Mine Safety and Health Administration (MSHA) of the Department of Labor was formed, replacing MESA, to set health and safety standards and to regulate the mining industry. In addition to MSHA regulations, some states have their own mining regulations. Two other government agencies perform research in the mining industry: the National Institute for Occupational Safety and Health (NIOSH), formed in 1970 under the Occupational Safety and Health Act, is responsible for conducting health and safety studies and recommending standards for the mining industry; the Bureau of Mines, in the Department of the Interior, conducts health and safety research.

\section{MILLING}

Uranium mills were licensed and regulated by the AEC or by agreement states until 1974, when the Energy Reorganization Act of 1974 transferred this responsibility to the NRC or agreement states. An agreement state refers to any state with which the regulatory agency has entered into an agreement under Section 274b of the Atomic Energy Act of 1954 (as amended) to conduct the licensing and regulation of facilities within that state. The first such agreement was initiated in 1962. Colorado, Florida, Louisiana, New Mexico, Texas, and Washington are agreement states that have milling operations today. Licensing requirements in agreement states must be no less stringent than those in NRC-licensed nonagreement states. Another regulatory agency that also has jurisdication over uranium mills is MSHA, which was given authority to enforce radiation and safety standards.

The licensing of uranium mills is governed by the Atomic Energy Act of 1954 (as amended). In nonagreement states, uranium mills that process or refine ores containing $0.05 \%$ or more of uranium by weight are required to have an NRC source material license. An application for such a license should be in accordance with the requirements of 10 CFR 40, "Licensing of Source Material." General guidance on the format and content of the license application is provided in NRC Regulatory Guide 3.5 (NRC 1977). In agreement states, a similar application must be presented to the appropriate state regulatory agency. 
Part of the regulatory procedure includes semiannual inspections of licensed mills by NRC inspectors or by state inspectors in agreement states. These inspections, along with periodic renewal of a mill's source material license, are used by regulators to verify that mills are complying with the conditions specified in the license.

Mills must comply with the radiation protection standards found in 10 CFR 20, "Standards for Protection Against Radiation." Initially written in January 1957 and updated annually, 10 CFR 20 has undergone over one hundred changes. In 1970, AEC started issuing safety guides (called regulatory guides today) to assist applicants and licensees in complying with the general requirements of the Code of Federal Regulations. Compliance with the regulatory guides themselves is not required; individual applicants or licensees may propose alternatives for new or existing programs that are not necessarily consistent with the guides. The justification for such alternatives is reviewed by the NRC staff and evaluated on a case-by-case basis.

Regulatory guides that are pertinent to evaluating occupational exposure in uranium mills are Regulatory Guides 8.15, Acceptable Programs for Respiratory Protection (NRC 1976a), and 8.22, Bioassay at Uranium Mills (NRC 1978a). In addition, two draft regulatory guides prepared by NRC are in the process of public review. These are entitled Health Physics Surveys in Uranium Mills and Information Relevant to Ensuring That Occupational Radiation Exposures at Uranium Mills Will Be As Low As Is Reasonably Achievable.

Bioassay ${ }^{(a)}$ results (particularly urinalysis results) would be of interest in health-related studies (e.g., trying to relate urinalysis results to uranium intake). Historically, urinalysis requirements have varied. In 1961, the AEC Division of Licensing and Regulation concluded that routine urinalysis was not necessary because it was an incomplete indicator of the presence of uranium (indicating exposure to soluble but not to insoluble forms) (AEC 1961). Although urinalysis continued to be conducted at a few mills after

(a) Bioassay - the determination of the kind, quantity or concentration, and location of radioactive material in the human body by direct (in vivo) measurement or by analysis of materials excreted or removed from the body (AEC 1974). 
1961, it was not until the renewal of the Atlas Mill license in October 1975 that NRC began to require bioassays at all uranium mills when licenses are issued or renewed (Alexander 1977). Urinalysis frequencies throughout the milling industry today are not standardized. During site visits, the following programs were observed:

- biweekly urinalysis for crusher building personnel and yellowcake workers

- biweekly urinalysis for al1 mill workers

- monthly urinalysis for yellowcake workers

- annual urinalysis for all mill workers.

\section{CONVERSION}

Historically, AEC and (since 1974) NRC have been responsible for licensing and regulating commercial uranium conversion facilities. Like uranium mills, conversion facilities must have a source material license to operate. Requirements for the license are given in 10 CFR 40 . Conversion facilities are also subject to inspections by NRC, must periodically renew the ir source material license, and must comply with the radiation protection standards in 10 CFR 20.

Regulatory guides that are pertinent to evaluating occupational exposure in conversion facilities include Regulatory Guide 8.11, Applications of Bioassay for Uranium (AEC 1974), and Regulatory Guide 8.15, Acceptable Programs for Respiratory Protection (NRC 1976a). Regulatory Guide 8.11 does not include recommendations for bioassay of the more highly transportable compounds $\mathrm{UF}_{6}$ and $\mathrm{UO}_{2} \mathrm{~F}_{2}$, which are present in conversion facilities.

\section{ENRICHMENT}

Since the Manhattan Project was begun, enrichment facilities have been regulated by federal agencies. Prior to the Energy Reorganization Act of 1974, AEC regulated the facilities. Since then, ERDA (1974 to 1977) and DOE (1977 to present) have regulated them. 
Today, all enrichment facilities are owned by DOE and operated by a private corporation under contract with $\mathrm{DOE}$. As mentioned above, these facilities are also regulated by $D O E$. Such facilities are not formally licensed. All contracts to operate DOE facilities contain a health and safety clause which stipulates that the facility will be operated in accordance with DOE (formerly ERDA) Manual chapters and/or DOE Orders. Because a DOE field office may amend the Manual chapters and/or Orders to "fit" a particular facility, the types of personnel protection programs at different facilities may vary even though they are all operated for DOE. Facilities owned by DOE contractors are routinely audited and appraised by DOE.

\section{FUEL FABRICATION}

Historically, AEC and (since 1974) NRC have been responsible for licensing and regulating commercial uranium fuel fabrication facilities. Fuel fabrication plants are licensed by NRC to process compounds that contain special nuclear materials. (a) Part 70 of 10 CFR specifies the information needed in license applications for the use of special nuclear materials. Regulatory Guide 3.39 (NRC 1976b), Standard Format and Content of License Applications for Plutonium Processing and Fuel Fabrication Plants, provides guidance on the preparation of an application for a special nuclear material license.

Regulatory guides that are pertinent to evaluating occupational exposures in fuel fabrication facilities include numbers 8.11, Application of Bioassay for Uranium (AEC 1974); 8.15, Acceptable Programs for Respiratory Protection (NRC 1976a); and 8.24, Health Physics Surveys During Enriched Uranium-235 Processing and Fuel Fabrication (NRC 1978b).

(a) Special nuclear material means 1) plutonium, uranium-233, uranium enriched in the isotope 233 or in the isotope 235, and any other material that NRC, pursuant to the provisions of Section 51 of the Atomic Energy Act of 1954, determines to be special nuclear material; or 2) any material artificially enriched by any of the foregoing (10 CFR 70). 


\section{CONCLUSIONS}

The current industry is regulated by numerous federal and state agencies. For example, MSHA and state agencies regulate uranium mines whereas NRC or agreement state agencies regulate uranium mills. This simultaneous regulation by many agencies has resulted in inconsistencies among radiation protection programs at similar types of facilities, because the same regulations may be interpreted and enforced in different ways by independent regulatory bodies. 


\section{RADIOLOGICAL HEALTH PRACTICES}

The purpose of this section is to describe general methods by which radiation hazards may be identified and controlled in uranium facilities. The four health physics practices discussed--facility monitoring, exposure control, exposure evaluation, and recordkeeping--have as their fundamental purpose the evaluation of exposure and the protection of the worker from unnecessary and potentially harmful exposure to radioactive materials.

The greatest potential pathway for the exposure of uranium industry workers is the inhalation of airborne radioactive contaminants. In uranium facilities, the breathing air is monitored for suspended uranium nuclides. The selection of monitoring locations and the frequency of sampling or measurements are determined by consideration of the quantities of radioactive materials in the production processes, their potential for escape from the system into the workplace, and their proximity to the worker.

Exposure control is achieved by the following: design engineering to prevent releases, respiratory protection programs, the use of other protective clothing, and employee training programs. The primary design features include containment dependability, dust collection systems, and indoor area ventilation and exhaust systems. The use of respirators is generally required during hazardous maintenance operations and where controls are insufficient to keep the concentration of uranium consistently below allowable limits.

Exposure evaluations are necessary to estimate worker exposures to uranium during normal operations and incidents. Methods include the determination of external gamma exposures, and bioassay (urinalys is and lung counting). External radiation exposure is measured using personnel dosimeters (thermoluminescence dosimeters (TLDs) or film badges). Throughout the uranium industry, urinalysis is a common method of determining whether uranium has been taken into the body. However, urinalys is alone cannot be relied on as an indicator of uranium taken into the body. This is particularly true for workers whose urinalys is frequency is less often than biweekly, as an accidental inhalation of a uranium compound may go undetected. For this reason, 
combinations of regular facility air monitoring, worker lung counting, fecal sampling, and nasal smears are used at many facilities in addition to urinalysis.

In evaluating a worker's exposure to uranium, it must be noted that uranium can present both a radiological and a chemical hazard to the body. The chemistry of a uranium compound determines its solubility in body tissues and, hence, its retention time in the body. All forms of uranium may accumulate through chronic exposures and remain in the body for long periods, resulting in a radiological hazard. Soluble forms also represent a chemical hazard and may damage kidney tissue. Insoluble uranium compounds of interest in the uranium industry include uranium oxide $\left(\mathrm{U}_{3} \mathrm{O}_{8}\right)$, uranium dioxide $\left(\mathrm{UO}_{2}\right)$, and uranium tetrafluoride $\left(U_{4}\right)$. Soluble compounds include ammonium diuranate $\left(\mathrm{NH}_{4}\right)_{2} \mathrm{U}_{2} \mathrm{O}_{7}$, uranium hexafluoride $\left(\mathrm{UF}_{6}\right)$, and uranyl fluoride $\left(\mathrm{UO}_{2} \mathrm{~F}_{2}\right)$. The solubility of inhaled uranium compounds is only one of many factors that need to be considered to achieve even a crude estimate of dose from internally deposited uranium. A review of factors involved in the dosimetry of uranium in the body is presented in Appendix $C$.

Recordkeeping includes maintaining records of facility monitoring and exposure evaluation data. Regulatory agencies require each licensed uranium facility to maintain such records.

Radiological health practices for each phase of the uranium industry are described in the following sections, based on information gathered during site visits and from reference materials. Conditions in the past would have varied considerably because of different regulatory requirements.

\section{MINING}

Radiological protection practices in uranium mines can reduce lung cancer incidences and other illnesses that might result from the inhalation of ore dust and radon and its daughter products, and from exposure to penetrating external gamma radiations. Uranium can be mined safely if the radiological hazards associated with the naturally occurring uranium decay series are understood and appropriately controlled. Mine workers are protected by limiting their exposure to ore dusts containing the long-lived alpha emitters $\left({ }^{238} U\right.$, 
${ }^{234} \mathrm{U},{ }^{230} \mathrm{Th},{ }^{226} \mathrm{Ra}$, and ${ }^{210} \mathrm{Po}$ ), radon and its short-lived daughters ( ${ }^{222} \mathrm{Rn}$, ${ }^{218} \mathrm{Po},{ }^{214} \mathrm{~Pb},{ }^{214} \mathrm{Bi}$, and $\left.{ }^{214} \mathrm{Po}\right)$, and external garma radiation. Exposure control is achieved by carefully monitoring the airborne radioactivity, design engineering to reduce the airborne concentrations, limiting worker access to areas that exceed radiation protection guidelines, and providing safety equipment when necessary.

Airborne radioactivity is regularly monitored in underground uranium mines using portable air sampling equipment. Quarterly air sampling for uranium ore dust is usually sufficient to demonstrate that the workers' annual exposure to long-lived alpha emitters is kept to less than operational limits. However, more frequent sampling may be necessary during unusually dusty working conditions. Air samples are collected by air filter pumps and analyzed for gross alpha activity. The recommended gross alpha quarterly limit is currently $35 \mathrm{pCi}-\mathrm{hr} / \mathrm{l}$ (air) (International Commission on Radiological Protection 1977).

The primary inhalation hazard is attributable to the buildup of radon and radon daughters in underground mine atmospheres. General air sampling for radon and its daughters is performed with portable instruments such as the working-level meter, which detects the alpha and beta activity of the sampled air and automatically displays the working level. Radon can also be measured in collected air samples using alpha scintillation chambers (Lucas flasks), or can be determined directly by the two-filter method (the first filter collects the radon daughters, and the second filter collects ${ }^{218}$ Po from the decay of radon in the tube separating the filters). Radon daughters can be measured using the modified Kusnetz method (IAEA 1976), which involves air sampling and filter counting followed by a second filter counting 40 to 90 min later. other methods such as the Rolle and the Tsivoglou methods (IAEA 1976) can also be used.

The annual average concentration of ${ }^{222} \mathrm{Rn}$ in equilibrium with its daughter products should not exceed $30 \mathrm{pCi} / \ell$, and occupational exposures to radon daughters should not exceed $4 \mathrm{WLM} / \mathrm{yr}$. Title 30 , Part 57 of the Code of Federal Regulations ( 30 CFR 57) requires individual exposure records to be kept for all employees entering an area with a radon daughter concentration in excess of $0.3 \mathrm{WL}$. 
External gamma radiation is monitored through the use of personnel dosimeter badges worn on the work clothing of the miners. If average gamma radiation levels exceed $2 \mathrm{mR} / \mathrm{hr}$ in the working place, personnel dosimeters must be provided and records of cumulative individual exposure kept, as required by 30 CFR 57.

Forced-air ventilation of underground mines is the most effective method of reducing airborne radioactivity (especially radon) in the drifts and stopes. The exhaust air is discharged to the surface. Abandoned stopes can be sealed off (using rock and a plastic foam sealant) to reduce radon levels in active areas of the mine. Air cleaning is also used in some mines to filter and electrostatically precipitate radon and radon daughters from mine atmospheres, although this practice is not widespread because of high costs.

Filter respirators (and sometimes even supplied-air respirators) are required in areas where air concentrations exceed certain operational levels. According to 30 CFR 57, respirators are required in areas exceeding $1 \mathrm{WL}$. Since the exposure limits are currently defined in terms of annual cumulative exposures, short-term exposures to high levels sometimes occur. These special situations underscore the need to closely monitor the workers' time-integrated exposure and maintain accurate exposure records to assure that overexposures do not take place.

Employee training programs are given at mines to teach the fundamentals of occupational health and safety. Such programs must meet the standards of the Federal Mine Safety and Health Act of 1977.

\section{MILLING}

Radiological health aspects of uranium milling operations differ from those of mining in that radon and its daughters are not the principal radionuclides of concern. In mills, workers are exposed to uranium ore dust and yellowcake. There is a potential for external exposure to gamma radiation because large volumes of ore are handled, but the radiation levels are usually quite low. Working conditions at uranium mills have improved during the past 
decade. Radiation protection programs have also improved as more knowledge about the effects and metabolism of uranium and its daughters in the body has been gained.

Radiation protection for workers in uranium mills is achieved by controlling the ambient levels of ore and yellowcake dust, and by establishing an adequate health physics program. This program includes regular air monitoring, surveys of work areas, respiratory protection, quality control, training and supervision of employees, an effective bioassay program, and recordkeeping.

Plant design and engineering initially determine the magnitude of the radiological health problems that must be dealt with by safety management. Containment dependability, dust collection and prevention, and indoor area ventilation are the primary design features that prevent airborne radioactive materials from reaching unacceptable levels. 0lder facilities usually require upgrading to meet the current requirements for dust control.

Facility monitoring is a method used to assess worker exposure. Ore pads, crusher buildings, and fine ore storage areas are usually monitored monthly or quarterly because ore dust is low in radioactivity. Air samples from these locations are analyzed by counting gross alpha activity using conventional alpha spectrometers. Operating conditions that are dustier than normal are sampled more frequently. The ore dust concentration of natural uranium in air is limited by 10 CFR 20 to $75 \mu \mathrm{g} / \mathrm{m}^{3}$. The liquid phases of the milling process are relatively dust free and are not monitored as frequently. Yellowcake dust is generated when the liquid concentrate is precipitated, dried, and packaged. Fixed-location (periodic and continuous) air sampling equipment and personal breathing zone samplers are used in this area of the mill, where the potential for an overexposure to uranium is greatest. Air filters are routinely collected (daily at end of shift) from continuous samplers. Weekly intakes of yellowcake dust are limited by 10 CFR 20 to $9.6 \mathrm{mg}$, which requires that concentrations of yellowcake dust in air be maintained below $200 \mu \mathrm{g} / \mathrm{m}^{3}$ of air. Respiratory equipment is usually required to prevent overexposures during the loading of barrels for product shipment. Radon daughter measurements, gamma surveys, and surface contamination smears are normally required as part of the overall monitoring program at uranium mills. 
Employee training programs are given at mills to teach the fundamentals of health protection and radiological safety. The topics covered include personal hygiene, radiation measurement methods, safety regulations, and emergency procedures.

Bioassay at uranium mills helps to indicate the adequacy of the radiological health program and the occurrence of overexposures to uranium. The frequency of urinalysis depends upon the ambient levels encountered; normally, a biweekly program is used. Bioassay results can provide guidance for corrective action. Chest counting of workers is rarely performed at uranium mills because of the unavailability of counting facilities and the high background count rates.

Records are kept, data evaluated, and audits performed at mills to identify trends and to maintain individual exposures within the limits in 10 CFR 20.

\section{CONVERSION}

Facility monitoring at conversion facilities consists of routinely sampling the breathing air in the working environment for airborne uranium and surveying work locations for surface contamination. Uranium can be found in the form of yellowcake, $U_{2}, U F_{4}$, or $U \mathrm{U}_{2} \mathrm{~F}_{2}$, depending on the location in the facility. Stationary samplers located throughout the general working areas collect airborne particulates on filter paper, which is removed at the end of each shift and counted for total activity. Portable air samplers and breathing zone samplers are used during maintenance or other nonroutine activities to provide correlation checks with the stationary samplers. No provision is made for quantitative real-time indication of high particulate concentrations in air. The results of the air sampling program are maintained for future reference. Contamination smears are taken routinely throughout the plant. Visual inspections for contamination are also conducted every shift.

As previously mentioned, the primary methods of exposure control are basic engineering design, respiratory protection programs, the use of protective clothing, and employee training programs. The engineering design features used at conversion facilities include the following: 
- ventilated hood in the yellowcake sampling area

- negative pressure system in the feed preparation phase to prevent the dispersion of uranium into the working environment

- totally enclosed systems (i.e., fluidized bed reactors that convert $\mathrm{U}_{3} \mathrm{O}_{8}$ feed to $\mathrm{UF}_{6}$ ).

Half-face masks with particulate filters provide routine respiratory protection for all workers. These respirators must be worn continuously in specified operating areas and during certain nonroutine activities. Full-face respirators with particulate canisters or supplied air are also available for use during maintenance activities. Personal contamination surveys are performed by employees when leaving radiation areas.

Exposure evaluation methods at conversion facilities include bioassay and determination of external garma exposure. The routine bioassay program requires all workers in uranium process areas to submit urine samples once every 2 weeks. These samples are analyzed for uranium content $(\mu \mathrm{g} / \mathrm{z})$ using the fluorometric analytical technique. Included in the routine bioassay program are lung counts once every 1 or 2 years. These are performed with onsite equipment or by a vendor-supplied mobile laboratory for whole-body counting.

Records of personnel exposures and facility monitoring results are maintained according to the requirements of 10 CFR 20 (Paragraph 20.401). These requirements include recording individual doses quarterly on appropriate forms, keeping individual exposure records until NRC authorizes disposition, and keeping facility monitoring data for 2 years after the survey except for data used in determining individual exposures.

\section{ENRICHMENT}

Facility monitoring at enrichment plants varies depending upon location. Because the diffusion cascade operates at a vacuum relative to atmospheric pressure, airborne uranium is normally not present. As a result, sampling for airborne particulates is not performed routinely. Instead, smoke detectors are used to alarm in the presence of any $\mathrm{UO}_{2} \mathrm{~F}_{2}$ formed following a release of $\mathrm{UF}_{6}$. Also, because $\mathrm{UO}_{2} \mathrm{~F}_{2}$ is highly visible as a white cloud, the release 
point can be rapidly identified. Decontamination and disassembly areas are sampled routinely for airborne particulates. Uranium is present in these areas as a corrosion oxide film of $\mathrm{UO}_{2} \mathrm{~F}_{2}$ and $\mathrm{UF}_{4}{ }_{4}$. These areas are also periodically surveyed for surface contamination. Maintenance shops are not routinely sampled for general airborne contamination, but are subject to local air sampling during special activities.

Exposures at enrichment facilities are controlled through the use of engineering design, personnel dosimeters, respiratory protection, and employee training. An example of engineering design is the provision of vacuum hoses at connections to $U_{6}$ cylinders to draw away any leakage during connection or disconnection. Respiratory protection is required during specified routine and maintenance activities. Whenever a connection to a $\mathrm{UF}_{6}$ system is made or broken (including drawing a $U_{6}$ sample or attaching a UF 6 cylinder to the cascade), a half-face mask is required. Respiratory protection is also required when cascade equipment is opened for maintenance, and during other maintenance activities such as grinding and cutting contaminated equipment.

Evaluation of exposures is accomplished through a program of lung counting, urinalysis, and external radiation monitoring. The frequency of urinalysis varies depending upon the type of work and its location. Workers with a potential for multiple low-level exposures (e.g., during the connecting and diconnecting of $U_{6}$ cylinders) are scheduled monthly, while all other workers are scheduled quarterly. Lung counts are performed annually for workers exposed to less soluble forms of uranium, for example, workers in the decontamination facility, compressor disassembiy mechanics, and some field maintenance workers. All other workers are counted every 2 years. External exposures are monitored through the use of TLD or film badges.

Lung count, urinalysis, and other monitoring and exposure data are kept for each employee. These records are maintained on a computerized data storage system for ease of retrieval. 


\section{FUEL FABRICATION}

Facility monitoring at fuel fabrication facilities includes sampling the air in work areas and surveying work locations for surface contamination. Breathing air in the working environment at fuel fabrication facilities is monitored for airborne particulate radioactivity by networks of fixed particulate samplers. These sampling networks are commonly a combination of breathing zone and general area air samplers. For example, there are few fixed work locations in the powder production process, leading to a greater dependence on general area samplers, while the pellet production process is made up of several specific work stations that lend themselves to breathing zone sampling. Lapel and high-volume air samplers are also used, but on a nonroutine bas is only. The particulate filters are collected at the end of each shift and counted for total activity. This method of sampling and analys is provides a post-exposure indication of air concentration. One fabrication facility uses an alpha air monitoring system to provide real-time indication of air concentration in selected areas. This system is set up to alarm in the event of excessive levels of airborne contamination. External radiation levels are monitored by semiroutine gamma surveys at most facilities and continuously at some facilities with dosimeters (TLDs or film) located throughout the process areas. Contamination surveys are conducted routinely, both visually and by smear samples.

The primary methods of exposure control are basic engineering design, respiratory protection programs, the use of protective clothing, and employee training programs. The engineering design features used at fuel fabrication facilities include ventilated hoods for the load-in and load-out procedures in the powder production phase, and bolted and gasketed enclosures for powderconveying equipment. Personnel internal exposures are controlled through the use of half- and full-face masks. Respiratory protection is required during the performance of tasks in areas with routinely high air concentrations. Most facilities have onsite mask-fitting and mask-testing equipment, and fit their personnel for more than one type of mask. At one facility, nasal smears are taken routinely at the end of each shift. 
Exposure evaluation methods at fuel fabrication facilities include bioassay and the determination of external gamma exposures. All of the fabrication facilities maintain routine bioassay programs (urinalysis and lung counting) to evaluate personnel exposures. Sample collection and lung count schedules are determined on the basis of work location or, in some cases, the employee's time-integrated exposure. In the latter case, the urinalysis schedule may change from one period to the next if the air concentrations used for determining exposure increase or decrease for any reason. The frequency of urine sample collection ranges from weekly to quarterly while that of lung counts ranges from quarterly to annually. Some of the larger facilities have onsite lung-counting equipment. Most facilities contract the urinalysis to private laboratories. Following an acute exposure, fecal samples are collected and urinalysis and lung count frequencies are increased. Personnel dosimeters (TLDs or film badges) are used to evaluate external total-body exposures. Dosimeters are evaluated either monthly or quarterly, depending on employee work location.

Records of personne 1 exposures and facility monitoring data are maintained according to the requirements of 10 CFR 20 (Paragraph 20.401). 
NONRADIOLOGICAL ASPECTS OF THE URANIUM INDUSTRY

In establishing any health-related study of the uranium industry, all possible exposures need to be considered. Radiological exposures have been outlined in previous sections of this report. In this section, nonradiological exposures are reviewed with respect to the interpretation of the health effects of radiological exposures. An example is the impact of diesel fumes and cigarette smoking on underground uranium workers, which has been under investigation (Archer and Wagoner 1973). In some instances, nonradiological exposures may be the dominant health hazard. In addition, it should be recognized that the industry is subject to the health exposures indigenous to all heavy industry, such as noise, welding fumes, grinding dusts, and industrial cleaning solutions.

\section{MINING}

The primary nonradiological hazards in underground uranium mining include the inhalation of dusts, diesel engine emissions, noxious gases from blasting, and oil mists from compressed-air drills. Physical stresses such as heat, noise, and vibration can also be significant. The major concern, somewhat unique to the mining phase, is the inhalation of fine respirable dust, particularly silica dust. Most uranium ore is found in sandstone formations, which contain free silica. Chronic inhalation of silica dust in high enough concentrations can cause the lung disease silicosis.

Concentration guides for mineral dusts, gases, and other nonradioactive airborne contaminants are published annually by the American Conference of Governmental Industrial Hygienists (ACGIH 1980). One category of concentration guides referred to as Threshold Limit Value-Time Weighted Average (TLV-TWA) is defined as the time-weighted average concentration for a normal 8-hr workday or 40-hr workweek, to which nearly all workers may be repeatedly exposed, day after day, without adverse effect (ACGIH 1980). The ACGIH's TLV for respirable silica dust in $\mathrm{mg} / \mathrm{m}^{3}$ is determined from the following formula: 


$$
\mathrm{TLV}=\frac{10 \mathrm{mg} / \mathrm{m}^{3}}{\% \text { respirable silica }+2}
$$

The 1 imit depends on the percentage of free respirable silica in the atmosphere and varies from $5 \mathrm{mg} / \mathrm{m}^{3}$ assuming no free respirable silica to a very restrictive value of $0.10 \mathrm{mg} / \mathrm{m}^{3}$ assuming $100 \%$ free respirable silica. The TLV for total dust (respirable and nonrespirable) in $\mathrm{mg} / \mathrm{m}^{3}$ is determined from the following formula:

$$
T L V=\frac{30 \mathrm{mg} / \mathrm{m}^{3}}{\% \text { respirable silica }+3}
$$

The limit depends on the amount of free silica in the atmosphere and varies from $10 \mathrm{mg} / \mathrm{m}^{3}$ to $0.30 \mathrm{mg} / \mathrm{m}^{3}$.

Two major methods are used to keep airborne dust concentrations and other pollutants below the concentration guides: 1) wetting during blasting and ore handling and dumping, and 2) intake of fresh air to dilute and remove pollutants.

Workers in open-pit mines have the potential for being exposed to similar nonradiological pollutants (siliceous ore dust and diesel engine exhaust emissions). However, the concentrations of these pollutants are generally not as significant as in underground mining because of the diluting effects of the atmosphere.

The incidence rates ${ }^{(a)}$ for fatalities and disabling injuries $(b)$ in the construction and operation of underground and open-pit uranium mines during 1979 were similar to those of other types of mining, particularly coal (MSHA 1980a and MSHA 1980b).

\footnotetext{
(a) Incidence rate - number of fatalities or injuries per 200,000 employeehours, rounded to two decimal places.

(b) Disabling injuries - nonfatal injuries that result in lost work days.
} 


\section{MILLING}

Nonradiological exposures in uranium mills are varied, and in fact are influenced by the milling process (conventional or unconventional).

In the conventional process, the inhalation of ore dust is again a major concern in the ore crushing area, particularly if the ore has a high free silica content. In the extraction, concentration, purification, and precipitation phases of milling, many chemicals are used including sulfuric acid, sulfates, carbonates, chlorides, nitrates, ammonia, lime, magnesia, and sodium hydroxide. Ammonia may present the greatest single potential for exposure. In the extraction phase, sulfur dioxide and sulfuric acid gases may be vented from leaching tanks. Although airborne concentrations of the gases are not known at this time, exposures are thought to be minimal since workers spend little time in the area. In addition, some mills have an exhaust system venting the tank gases to the outside. In the concentration and purification phase, solvent extraction tanks exhaust vapors from the kerosene-based liquid through roof vents, and worker exposures are low as long as the ventilation system is intact and functioning properly.

The unique nonradiological hazards associated with uranium recovery operations (a type of unconventional milling) depend upon whether or not the uranium recovery plant is adjacent to the phosphate facility. When the uranium recovery $\mathrm{plant}$ is located close to the phosphate facility, general emissions from phosphate processing operations, which include fluorides and sulfur dioxide, may pose a greater hazard to uranium recovery workers than anything they are directly exposed to in their work environment. Depending on the process used, workers also have a potential exposure to ammonia, hydrogen peroxide, kerosene, alcohol, hot sulfuric acid, phosphate anhydrites, and sodium fluorosilicate. From a practical standpoint, ammonia again seems to present the greatest single potential for exposure.

In the solution mining process (another type of unconventional milling), unique potential hazards during the drilling of injection and recovery wells include exposure to noise and again the possibility of dust containing silica. The chemicals used to make up the injection solution, such as hydrochloric acid, are not considered a significant inhalation hazard, but are noteworthy 
from a handling standpoint. Operations for installing and inserting the piping network that connects the systems also present minimal health hazards.

Maintenance operations involved in the upkeep and installation of equipment are common to all milling operations. These result in potential exposures to such contaminants as welding fumes, grinding dusts, particulates, and industrial cleaning solutions. However, the significance of such hazards is comparable to that experienced in other heavy industry operations.

The incidence rates for fatalities and disabling injuries in the operation of uranium mills during 1979 were similar to those of other types of milling (MSHA 1980a and MSHA 1980b).

\section{CONVERSION}

Nonradiological health exposures are directly related to the steps involved in the conversion of yellowcake to volatile UF 6 . In the feed preparation phase of the wet process, nitric acid is used for digestion of the ore, and potential exposures to $\mathrm{NO}_{2}-\mathrm{NO}_{x}$ gases are thus possible. One facility maintains the tanks under vacuum, but $\mathrm{NO}_{2}$ occasionally escapes into the room. On the basis of extensive $\mathrm{NO}_{2}$ monitoring, it appears that no chronic $\mathrm{NO}_{2}$ exposure problem exists. The TLV-TWA for $\mathrm{NO}_{2}$ is $5 \mathrm{ppm}$.

In the conversion phase, cracked ammonia is used to reduce the $\mathrm{U}_{3} \mathrm{O}_{8}$ and $\mathrm{UO}_{3}$ to $\mathrm{UO}_{2}$. The use of large quantities of anhydrous ammonia may represent the most significant potential for an exposure. At one facility, ammonia odor was noticeable in the solvent extraction area, but the concentration is reportedly 5 to $10 \mathrm{ppm}$ most of the time. The TLV-TWA for ammonia in air is $25 \mathrm{ppm}$ (ACGIH 1980). The hydrofluorinators in the conversion phase present potential exposures to fluorides, hydrogen fluoride, hydrogen sulfide, and oxides of nitrogen. It is thought that any fluoride exposure problem would be environmental and not occupational. Nonetheless, at one facility, monthly urinary fluoride analyses are performed for production and maintenance personnel. Exposures to off-gases are thought to occur mainly during accidental leaks. 
Other chemicals to which workers in a conversion facility may be exposed include tributyl phosphate and hexane in the solvent extraction area of the purification phase, and fluorine gas generated by the electrolysis of potassium fluoride with a hydrogen fluoride feed in the conversion phase.

\section{ENRICHMENT}

In the enrichment process area, low levels of fluorides exist at times. Any leakage of $U_{6}$ to the atmosphere results in the formation of uranyl fluoride $\left(\mathrm{UO}_{2} \mathrm{~F}_{2}\right)$ and hydrogen fluoride ( $\mathrm{HF}$ ) gas. Maintenance personnel are most likely to receive exposures, during repair of improperly functioning cells containing trapped $\mathrm{UF}_{6}$. The likelihood of exposure is greatly reduced for these workers, however, because this hazard is well known and a rigid respiratory protection program is followed. An inadvertent leak would be more likely to produce a high but brief exposure to the surrounding workmen. Since the gas is visible in air, the source could be quickly identified and repaired. This rapid identification via observation decreases the occurrence of significant exposures.

Because $U_{6}$ is highly corrosive, much of the piping throughout the enrichment system is nickel or stainless steel. This presents a concern during welding regarding potential exposures to nickel and chrome fumes, which are suspected carcinogens. Nickel exposures are also possible during the manufacturing of the diffusion barrier, which is a special porous medium used in the enrichment process. A metallic nickel powder is used in barrier production. A recently completed study was designed to ascertain whether mortality from respiratory cancer among barrier workers exposed to airborne metallic nickel differed from that among plant employees with no occupational exposures (Godbold and Tompkins 1979). The results of the study do not support the contention that there is a substantial risk of respiratory malignancies to workers exposed to this nickel material. Other contaminants in the enrichment process include asbestos, sulfuric acid, and fluorides.

Air monitoring and urinalysis programs are conducted for the detection of contaminants at enrichment facilities. Sampling frequencies for urinalysis vary depending upon exposures. Action levels for 28 urinary contaminants have been established at one facility. 


\section{FUEL FABRICATION}

The most prevalent nonradiological exposure throughout fuel fabrication facilities is to ammonia used in the powder production phase. In one facility visited, a strong odor of ammonia gas was noticeable in the autoclave area, but the gas was reportedly coming from the ammonia recovery $p l a n t$. There, a wastereceiving tank is vented to the atmosphere in a manner that occasionally causes ammonia to return to the plant. Concentrations as high as $15 \mathrm{ppm}$ are not uncommon, and a scrubber to prevent gas recirculation is to be added to the system. The TLV-TWA for ammonia in air is 25 ppm (ACGIH 1980). In another facility, an ammonium hydroxide tank in the ADU area had a plugged line, and the solution had backed up and spilled onto the floor. This was considered to produce an airborne ammonia level of 75 to $100 \mathrm{ppm}$ (the "normal" level is reportedly 5 to $10 \mathrm{ppm}$ ). The floor looked as if many spills or leaks have occurred. In order to determine ammonia levels in this area, breathing zone and area samples are taken periodically.

After the ADU and $\mathrm{U}_{3} \mathrm{O}_{8}$ are calcined in the powder production phase, additional potential for fluoride exposure exists. In all facilities visited, occupational exposures to fluorides are extremely low, and the concern with respect to fluorides is environmental (from stack emissions). This conclusion was based on past monitoring activities.

In the fuel assembly phase, completed fuel assemblies are cleaned with acetone, which is obtained from a dispenser and manually wiped onto the assemblies. Although no quantitative data were available, exposure to acetone may present a problem.

Nitric acid is used to dissolve uranium in waste recovery operations. Nitric acid is also used for cleaning purposes at the ammoniator. These operations involve potential exposures to peak concentrations of $\mathrm{NO}_{2}-\mathrm{NO}_{X}$, especially during the opening of digester doors. Sampling has been done for oxides of nitrogen at the facilities. Perchloroethylene and tributyl phosphate are used in conjunction with nitric acid for waste cleanup in at least one facility. Exposures to these vapors reportedly are not excessive. 
Another area of potential airborne ammonia is in the radioactive waste area where ammonium hydroxide is used. Normal gas levels here are 30 to $50 \mathrm{ppm}$, and the odor of ammonia was easily noticeable during our visit. For this and all areas where spills or leaks may occur, cleanup is usually accomplished by a simple mopping procedure. This suggests that maintenance personnel may be exposed to the highest ammonia concentrations found in fuel fabrication.

Other chemicals of interest used in fabrication include trichloroethylene, trichloroethane, hydrofluoric acid, sodium hydroxide, and hydrochloric acid. A variety of the potential hazards common to the rest of the uranium industry are also found in fuel fabrication, for instance welding and metal-cleaning procedures. 


\section{U.S. URANIUM REGISTRY TISSUE PROGRAM}

The preceeding sections of this report have briefly characterized the facilities, processes, radiological aspects, and industrial hygiene aspects of the uranium industry. It has been shown that the potential exists for occupational exposure to many different chemical forms of uranium. The deposition, metabolism, and retention of these compounds in man are not completely understood. Information about these processes can be obtained from post-mortem study of uranium workers with a previous history of uranium exposure.

One of the Registry's most important accomplishments has been to establish a post-mortem tissue study program, which represents the first systematic effort to contact and gain the assistance of workers exposed to uranium. The program objectives, the procedures for enrolling workers in the program, the types of tissue to be studied, and the analytic procedures to be used are discussed in this section.

The tissue program of the USUR is patterned after that of the U.S. Transuranium Registry (USTR), which has been operated since 1968 by HEHF with support from PNL. The USTR has been sponsored successively by AEC, ERDA, and DOE. During the 12 years of its operation, the USTR has enrolled in the program a total of over 1000 persons from six government-contractor-operated and six private facilities, and 845 valid autopsy permits are currently on file for future donation of tissues. The Registry has finished processing tissues and data from 76 autopsies, with 29 remaining to be completed, and is in the late stages of analyzing a donated whole body. In addition, scientists of the United Kingdom have provided to the Registry data obtained from 35 autopsies of transuranic workers. The work of the USTR has been described in several reports and publications, $(a)$ and the experience gained during its operation has been used in developing the tissue program of the USUR.

In contrast to the substantial past interest in tissue concentrations of transuranic elements, interest in analyses of human tissue for uranium has

(a) Norwood 1969; Norcross and Newton 1972; Norwood 1970; Norwood and Newton 1975; Norwood et al. 1972; Breitenstein 1979. 
been limited, and such studies have been carried out only sporadically, either as an incidental feature in a transuranic tissue study (ERDA 1975) or in isolated cases. (a) The need for dedicated studies of tissue distribution similar to those of the USTR and for epidemiologic studies of uranium exposure was identified by Boback, Darr, Finkel, Heid, Ross, and Sterner during the ERDAsponsored Conference on Occupational Health Experience in 1975 (ERDA 1975). The tissue program of the USUR represents the first systematic effort to enroll workers exposed to uranium in a program of post-mortem tissue study.

The objectives of the USUR tissue program are to:

1. determine the distribution and levels of uranium in the tissues of occupationally exposed workers

2. compare bioassay measurements of exposed individuals with the results of analyses of tissues obtained at autopsy

3. seek evidence of histopathologic changes related to any uranium deposition that may be present

4. conduct analyses of whole bodies, when available, to obtain more precise data on the uranium burdens, if any, in the body and organs and especially the distribution in parts of the body, such as most of the skeleton, that are not usually accessible for sampling.

Workers in uranium-handling facilities are enrolled in the program through the cooperative efforts of USUR staff and the medical, industrial relations, or health physics personnel of the facilities. The majority of volunteers are likely to be enrolled by medical personnel at the time of their physical examination or by health physics personnel at the time of a bioassay or lung counting procedure. During enrollment, a simple occupational history is obtained, and permission is gained for access to the worker's medical history and exposure data. The agreement signed by the individual runs for a period of 5 years; the USUR usually seeks to renew the agreement upon its expiration. While this agreement provides permission for an autopsy, experience has shown

(a) Quigley, Heatherton and Ziegler 1959; Heatherton, Boback and Quigley 1963; Roberts, Coulston and Bates 1977; Berdnikova 1970. 
that another autopsy permit may be required at the time of death to satisfy hospital and state authorities. For this reason, it is important that the next of kin be aware of the program at an early date and be agreeable to the volunteer's participation in the Registry's tissue program. An alternative to pre-enrollment is to obtain after death the consent of next of $k$ in to the analysis of tissues removed during an autopsy. Follow-up after initial contacts is carried out by on-site plant personnel, but subsequent follow-up is the responsibility of the Registry. The next of kin receives a $\$ 500$ stipend when the autopsy is completed, as a gesture of appreciation for the registrant's willingness to participate in this important scientific program and his cooperation in keeping the USUR informed of his place of residence.

The Registry maintains a system by means of which calls may be received at any time of day or night at (509) 376-7987. This system permits a rapid response in the event of the death of a registrant so that the pathologist conducting the autopsy may be aware of the requirements of the Registry for specific organs and tissues for analysis. Instructions are also provided for the processing and transport of the tissues to Richland, Washington, for radiochemical analysis.

The Registry recommends the use of standard procedures in the performance of the autopsy. On the advice of experts, we request the following tissues:

1. Lung - right and left (whole)

2. Lymph nodes (hilar)

3. Liver (whole or minimum $400 \mathrm{~g}$ )

4. Bone:

Ribs - one or more whole ribs, excluding 1, 2, 11, and 12 Sternum (whole)

Vertebrae - vertebral wedge Patella

5. Spleen (whole)

6. Thyroid (whole)

7. Kidneys - right and left (whole)

8. Ovaries or testes (both)

9. Tumor, if any

10. Blood from heart $(10 \mathrm{ml})$

11. Muscle - iliopsoas

12. Fat from abdomen (panniculus)

13. Skin from both sides of abdominal incision, and subcutaneous fat

14. Calvarium and brain, only if brain is removed as part of regular autopsy. 
The organs of particular interest are the skeleton, lungs, tracheobronchial lymph nodes, and kidneys. In past studies, these organs have been demonstrated either to have the highest concentrations of uranium or to show the greatest effect from uranium. (a) The above list is subject to revision in the light of future developments.

Upon completion of the autopsy report by the pathologist who conducted the autopsy, a copy of the report will be obtained by the USUR. A set of histologic slides will be obtained for examination by pathologist consultants to the Registry. In addition to the death certificate, any available medical records, health physics data, and other occupational exposure data will be procured.

Analysis of the uranium concentrations in the tissues will be carried out by PNL using neutron activation analysis. This procedure involves neutron activation of a dried tissue sample by exposure to a flux of approximately $10^{14} \mathrm{n} / \mathrm{s}$ for $30 \mathrm{~min}$. Following a decay period of $24 \mathrm{hr}$, gamma spectroscopy is performed. The ${ }^{239} \mathrm{~Np}$ activity detected can be correlated to the original amount of ${ }^{238} \mathrm{U}$ in the sample. After the activated sample has decayed for about 3 weeks, the ${ }^{235} \mathrm{U}$ leve 1 can be determined through gamma spectroscopy, by relating the ${ }^{140} \mathrm{Ba}-\mathrm{La}$ activity to the original ${ }^{235} \mathrm{U}$ levels. The ${ }^{235} \mathrm{U}$ analysis will be performed only on samples for which the isotopic mixture of the individual's exposure is unknown.

Individuals who were exposed to uranium prior to the existence of modern exposure standards are presently being enrolled by the USUR. The reliability of concentration and distribution data and the demonstration of effects is more likely in such individuals than in those who have received less exposure. However, ample attention will be given to those who were less exposed and even to exposed workers with no record of intake of uranium. The lesser exposures are of immediate interest because of the rarity of heavy exposures under current standards. The sampling of potentially exposed individuals with negative in-vivo measurements results may serve to check the adequacy of in-vivo measurements in the detection of deposition.

(a) ERDA 1975; Quigley, Heatherton and Ziegler 1959; Heatherton, Boback and Quigley 1963; Roberts, Coulston and Bates 1977; Berdnikova 1970; Hodge, Stannard and Hursh 1973. 
The USUR tissue program will develop data that will assist in evaluating the accuracy of current in-vivo measurement techniques. The data will also be useful in assessing models of distribution and excretion of uranium in man and the assumptions underlying those models. In developing these data, the Registry will contribute to the evaluation of the propriety of existing standards and the adequacy of current health protection programs. 


\section{REFERENCES}

Alexander, R. E. 1977. "NRC Rationale for Bioassay Requirements." In Workshop on Methods for Measuring Radiation in and Around Uranium Mills. $\overline{\text { Atomic }}$ Industrial Forum, Inc., New York, New York.

American Conference of Governmental Industrial Hygienists, Inc. 1980. Documentation of Threshold Limit Values. 4th ed. Cincinnati, Ohio.

Archer, V. E., and J. K. Wagoner. 1973. "Lung Cancer Among Uranium Miners in the United States." Health Phys. 25:351-371.

Berdnikova, A. V. 1970. Faktory Vneshnei Sredy ikh Znachenie dlya Zdorovya, No. 2 pp. 135-137, 1970. Translated by Linda Nobylenski, Office of Language Services, Oak Ridge National Laboratory, Oak Ridge, Tennessee.

Breitenstein, B. D., Jr. 1979. "The U.S. Transuranium Registry." Presented at Workshop on Measurement and Interpretation of Actinide Accumulation by Man, Snowbird, Utah, October 14-18, 1979. (Proceedings will be published during 1981).

Clark, D. A. 1974. State-of-the-Art: Uranium Mining, Milling, and Refining Industry. EPA-660/2-74-038, U.S. Environmental Protection Agency, Washington, D.C.

Cooke, N., and F. B. Holt. 1974. "The Solubility of Some Uranium Compounds in Simulated Lung Fluid." Health Phys. 27:69-77.

Cool, W. S. 1978. Occupational Radiation Exposure at NRC-Licensed Facilities, 1975. NUREG-0419, U.S. Nuclear Regulatory Commission, Washington, D.C.

Dennis, N. A., and H. M. Blauer. 1979. Dissolution Rates of Yellowcake in Simulated Lung Fluids. Master's Thesis, University of Pittsburgh, Pittsburgh, Pennsylvania.

Eidson, A. F., and J. A. Mewhinney. 1978. In Vitro Dissolution of Uranium Product Samples from Four Uranium Mi11s. NUREG/CR-0414, U.S. Nuclear Regulatory Commission, Washington, D.C.

Eidson, A. F., and J. A. Mewhinney. 1980. "In Vitro Solubility of Yellowcake Samples from Four Uranium Mills and the Implications for Bioassay Interpretation." Health Phys. 39:893-902.

Federal Radiation Council. 1967. Guidance for the Control of Radiation Hazards in Uranium Mining. Report No. 8, Federal Radiation Council, Washington, D.C. 
Godbold, J. H., Jr., and E. A. Tompkins. 1979. "A Long-Term Mortality Study of Workers Occupationally Exposed to Metallic Nickel at the Oak Ridge Gaseous Diffusion Plant." J. Occ. Med. 21(12):799-806.

Goldsmith, W. A. 1976. "Radiological Aspects of Inactive Uranium Milling Sites: An Overview." Nuclear Safety 17(6):722-732.

Heatherton, R. C., M. W. Boback, and J. A. Quigley. 1963. "A Continued Program for Analysis of Uranium in Human and Animal Tissues." In Proceedings of the Ninth Annual Conference on Bioassay and Analytical Chemistry, p. 181. TID-7696, U.S. Atomic Energy Commission, Washington, D.C. AvaiTable from National Technical Information Service, Springfield, Virginia.

Hodge, H. C., J. N. Stannard and J. B. Hursh, eds. 1973. Uranium-Plutonium Transplutonic Elements. Handbook of Experimental Pharmacology XXXVI, Springer-Verlag, New York, New York.

International Atomic Energy Agency. 1976. Manual on Radiological Safety in Uranium and Thorium Mines and Mills. IAEA Safety Series No. 43, Vienna, Austria.

International Commission on Radiological Protection (ICRP). 1977. Radiation Protection in Uranium and Other Mines. Pergamon Press, 0xford.

Kalkwarf, D. R. 1979. Solubility Classification of Airborne Products from Uranium Ores and Tailings Piles. PNL-2870, NUREG/CR-0530, Pacific Northwest Laboratory, Richland, Washington.

McGinley, F. E. 1975. "Effects of Stricter Radiation Exposure Standards on Uranium Costs and Ore Reserves." In Proceedings of a Panel on Radon in Uranium Mining, pp. 3-14, STI/PUB/391, International Atomic Energy Agency, Vienna, Austria.

Merritt, R. C. 1971. The Extractive Metallurgy of Uranium. Colorado School of Mines, Research Institute, Golden, Colorado.

Miller, H. T., and L. M. Scott. 1980. "Radiation Exposures Associated with Exploration, Mining, Milling, and Shipping of Uranium." Paper presented at the Twenty-Fifth Annual Health Physics Society Meeting, Seattle, WA. Available from Gulf Science and Technology Company, Pittsburgh, Pennsylvania.

National Research Council, Committee on the Biological Effects of Ionizing Radiation. 1980. The Effects on Populations of Exposures to Low Levels of Ionizing Radiation. National Academy of Sciences, Washington, D.C.

Norcross, J. A., and C. E. Newton, Jr. 1972. "U.S. Transuranium Registry: A Progress Report." Health Phys. 22:887-890.

Norwood, W. D. 1970. "U.S. Transuranium Registry - Progress and Expectations." In Proceedings: Radiobiology of Plutonium, B. J. Stover and S. S. Webster, eds. J. W. Press, Salt Lake City, Utah. 
Norwood, W. D. 1971. "U.S. National Plutonium Registry." In Proceedings of the Sixteenth International Congress on Occupational Health, Tokyo, Japan, September 22, 1969. Japan Industrial Safety Association, Tokyo.

Norwood, W. D., and C. E. Newton, Jr. 1975. "U.S. Transuranium Registry Study of Thirty Autopsies." Health Phys. 28:669-675.

Norwood, W. D., J. A. Norcross, C. E. Newton, Jr., D. B. Hylton and C. Lagerquist. 1973. "Preliminary Autopsy Findings in U.S. Transuranium Registry Cases." In Radionuclide Carcinogenesis: Proceedings of the Twe lfth Annual Hanford Biology Symposium, C. L. Sanders et al., eds. AEC Symposium Series 29, CONF-720505, National Technical Information Service, Springfield, Virginia.

Quigley, J. A., R. C. Heatherton and J. F. Ziegler. 1959. "Studies on Human Exposure to Uranium." In Symposium on 0ccupational Health Experience and Practices in Uranium Industry, New York City, October 15-17, 1958, p. 34. HASL-58, U.S. Atomic Energy Commission, Health and Safety Laboratory, New York, New York. Available from DOE Office of Technical Service, Washington, D.C.

Roberts, A. M., D. J. Coulston and T. H. Bates. 1977. "Confirmation of In-Vivo Uranium in Chest Survey by Analysis of Autopsy Specimens." Health Phys. 32:435-437.

U.S. Atomic Energy Commission (AEC). 1961. Letter to Uranium Reduction Company, Moab, Utah, June 26, 1961. Available in U.S. NRC Document Room, Washington, D.C.

U.S. Atomic Energy Commission (AEC). 1974. Applications of Bioassay for Uranium. Regulatory Guide 8.11, Washington, D.C.

U.S. Code of Federal Regulations, Title 10, Part 20, "Standards for Protection Against Radiation" (1980).

U.S. Code of Federal Regulations, Title 10, Part 40, "Licensing of Source Material" (1980).

U.S. Code of Federal Regulations, Title 10, Part 70, "Special Nuclear Materia1" (1980).

U.S. Code of Federal Regulations, Title 30, Part 57, "Health and Safety Standards - Metal and Nonmetallic Underground Mines" (1980).

U.S. Department of Energy (DOE). 1980. Statistical Data of the Uranium Industry. GJ0-100 (80), DOE Grand Junction Office, Grand Junction, Colorado.

U.S. Department of Labor, Mine Safety and Health Administration (MSHA). 1980a. Injury Experience in Coal Mining, 1979. IR 1122, Washington, D.C. 
U.S. Department of Labor, Mine Safety and Health Administration (MSHA). 1980 . Injury Experience in Metallic Mineral Mining, 1979. IR 1126, Washington, D.C.

U.S. Energy Research and Development Administration (ERDA). 1975. Conference on Occupational Health Experience with Uranium. ERDA-93, Washington, D.C.

U.S. Environmental Protection Agency (EPA). 1977. Radiation Protection Activities - 1977. EPA-520/4-78-003, Washington, D.C.

U.S. Nuclear Regulatory Commission (NRC). 1976a. Acceptable Programs for Respiratory Protection. Regulatory Guide 8.15, washington, D.C.

U.S. Nuclear Regulatory Commission (NRC). 1976b. Standard Format and Content of License Applications for Plutonium Processing and Fuel Fabrication Plants. ReguTatory Guide 3.39, Washington, D.C.

U.S. Nuclear Regulatory Commission (NRC). 1977. Standard Format and Content of License Applications for Uranium Mills. ReguTatory Guide 3.5 (Revision 1), Washington, D.C.

U.S. Nuclear Regulatory Commission (NRC). 1978a. Bioassay at Uranium Mills. Regulatory Guide 8.22, Washington, D.C.

U.S. Nuclear Regulatory Commission (NRC). 1978b. Health Physics Surveys During Enriched Uranium-235 Processing and Fuel Fabrication. Regulatory Guide 8.24, Washington, D.C.

U.S. Nuclear Regulatory Commission (NRC). 1979. Draft Generic Environmental Impact Statement on Uranium Milling. NUREG-0511, NRC Office of Nuclear Material Safety and Safeguards, Washington, D.C.

U.S. Nuclear Regulatory Commission (NRC). 1980. Final Generic Environmental Impact Statement on Uranium Milling. NUREG-0706, Washington, D.C.

Wilhe $1 m$, H. A. 1960. "Development of Uranium Metal Production in America." J. Chem. Educ. $37(2): 56-68$. 


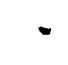




\section{APPENDIX A}

\section{FACILITIES VISITED BY URANIUM REGISTRY PERSONNEL}


APPENDIX A

FACILITIES VISITED BY URANIUM REGISTRY PERSONNEL

\section{Company}

1. Kerr-McGee

2. Western Nuclear

3. Dawn Mining Company

4. Exxon

5. Federal-American Partners

6. Union Carbide

7. Union Carbide

8. Western Nuclear

9. Kerr-McGee

10. Rio Algom

11. UNC-Homestake Partners

12. New Wales Chemical/ IMC Corp.

13. Wyoming Minerals Corp./ Farml and Industry

14. UNC Recovery Corp./ W.R. Grace \& Company

15. Gardinier

16. Wyoming Minerals Corp. - Lamprecht

17. Wyoming Minerals Corp. - Bruni

18. United States Stee 1
Facility Type

Mine (underground)

Mine (open-pit)

Mill

Mill

Mil1

Mill

Mill

Mi11

Mill

Mill

Mi11

Uranium Recovery

Uranium Recovery

Uranium Recovery

Uranium Recovery

Solution Mine

Solution Mine

Solution Mine
Location

Grants, NM

Wellpinit, WA

Ford, WA

Douglas, WY

Gas Hills, WY

Gas Hills, WY

Uravan, CO

Wellpinit, WA

Grants, NM

Moab, UT

Grants, NM

Lakeland, FL

Pierce, FL

Mulberry, FL

Tampa, FL

Ray Point, TX

Bruni, TX

George West, TX 
Company

19. United States Steel Niagara Mohawk

20. Wyoming Minerals Corp. Kennecott Copper

21. Kerr-McGee

22. Allied Chemical

23. Department of Energy

24. Department of Energy

25. Babcock \& Wilcox

26. Babcock \& Wilcox

27. General Electric

28. Westinghouse

29. Exxon

30. Combustion Engineering

31. United Nuclear Corp.

32. General Electric

33. Atomic International

34. Nationa 1 Lead

35. Rockwell Hanford Co.
Facility Type

Solution Mine

Heap Leach

Conversion

Conversion

Enrichment

Enrichment

Fuel Fabrication

Fuel Fabrication

Fuel Fabrication

Fuel Fabrication

Fuel Fabrication

Fuel Fabrication

Naval Fuel Fabrication

Former Uranium Facility

Uranium Research and Development

Special - U feed materials into U metal

Uranium Calcining
Location

George West, TX

Bingham Canyon, UT

Gore, OK

Metropolis, IL

Oak Ridge, TN

Paducah, KY

Apollo, PA

Lynchburg, VA

Wilmington, NC

Columbia, SC

Richland, WA

Windsor, CT

Uncasville, CT

San Jose, CA

Canoga Park, CA

Fernald, $\mathrm{OH}$

Richland, WA 
APPENDIX B

RADIOLOGICAL PROPERTIES OF URANIUM 
APPENDIX B

\section{RADIOLOGICAL PROPERTIES OF URANIUM}

The typical worldwide concentration of natural uranium in soil ranges from 1 to $4 \mathrm{ppm}$ with an average of $2 \mathrm{ppm}$ (0.0002\% uranium) (National Council on Radiation Protection and Measurement 1976). Ores recovered by conventional mining methods (open-pit and underground) contain an average of $1300 \mathrm{ppm}$ uranium (0.13\% uranium). Unconventional mining methods (solution mining, uranium recovery, and heap leaching) are generally used to extract ores containing 50 to $200 \mathrm{ppm}$ uranium $(0.005$ to $0.02 \%$ uranium) .

\section{ISOTOPIC COMPOSITION}

In nature, uranium exists as a composite of three primary isotopes: ${ }^{238} \mathrm{U},{ }^{235} \mathrm{U}$, and ${ }^{234} \mathrm{U}$. The relative abundance of the isotopes is $99.274 \%$ ${ }^{238} \mathrm{U}, 0.720 \%{ }^{235} \mathrm{U}$, and $0.005 \%{ }^{234} \mathrm{U}$ (ERDA 1975). Uranium exists in these isotopic proportions throughout the mining, milling, and conversion phases of the uranium fuel cycle.

Uranium is enriched to between 2 and 4 wt\% ${ }^{235} U$ at enrichment plants for use in commercial fuel fabrication. A by-product of the enrichment process is depleted uranium, which is low in ${ }^{235} U$ content. Typical weight percents of the uranium isotopes in enriched and depleted uranium (ERDA 1975) are:

\begin{tabular}{|c|c|c|}
\hline \multirow{2}{*}{ Isotope } & \multirow{2}{*}{\multicolumn{2}{|c|}{$\begin{array}{l}\text { Isotopic Content (wt\%) of } \\
\text { Enriched } U\end{array}$}} \\
\hline & & \\
\hline${ }^{238} U$ & 97.01 & 99.75 \\
\hline & 2.96 & 0.25 \\
\hline${ }^{234} U$ & 0.03 & 0.0005 \\
\hline
\end{tabular}

DECAY SERIES

Three decay series occur naturally in the earth's crust: the thorium series (parent - ${ }^{232} \mathrm{Th}$ ), the uranium series (parent $-{ }^{238} \mathrm{U}$ ), and the actinium series (parent $-{ }^{235} \mathrm{U}$ ). The uranium series is of primary importance in the 
commercial fuel industry. The decay scheme of the uranium series is shown in Figure B.1. Daughters of ${ }^{238} U$ in unprocessed uranium are in secular equilibrium $^{(a)}$ unless a condition or process removes one or more of the decay products from the chain. One such condition occurs when gaseous ${ }^{222} \mathrm{Rn}$, the daughter of ${ }^{226} \mathrm{Ra}$, disperses into the atmosphere. The emanation of radon gas from uranium ore is of concern during mining. Radon decays to several shortlived daughters, ${ }^{218} \mathrm{Po},{ }^{214} \mathrm{~Pb},{ }^{214} \mathrm{Bi}$, and ${ }^{214} \mathrm{Po}$, which can either attach to dust particles or remain unattached in the atomosphere. Because of their short half-lives, radon daughters will release most of their energy in the lung when inhaled.

Most ${ }^{238} \mathrm{U}$ daughter products are chemically removed during the milling process, resulting in an end product of between $80 \%$ and $95 \%$ uranium. Two daughters, ${ }^{234} \mathrm{Th}$ and ${ }^{234} \mathrm{~Pa}$, will build back to approximately $70 \%$ secular equilibrium in 30 days.

(a) Secular equilibrium - a state of radioactive equilibrium in which the half-life of the parent is much longer than that of the daughter, resulting in equal activities $(\mathrm{C} i$ ) of parent and daughter. 


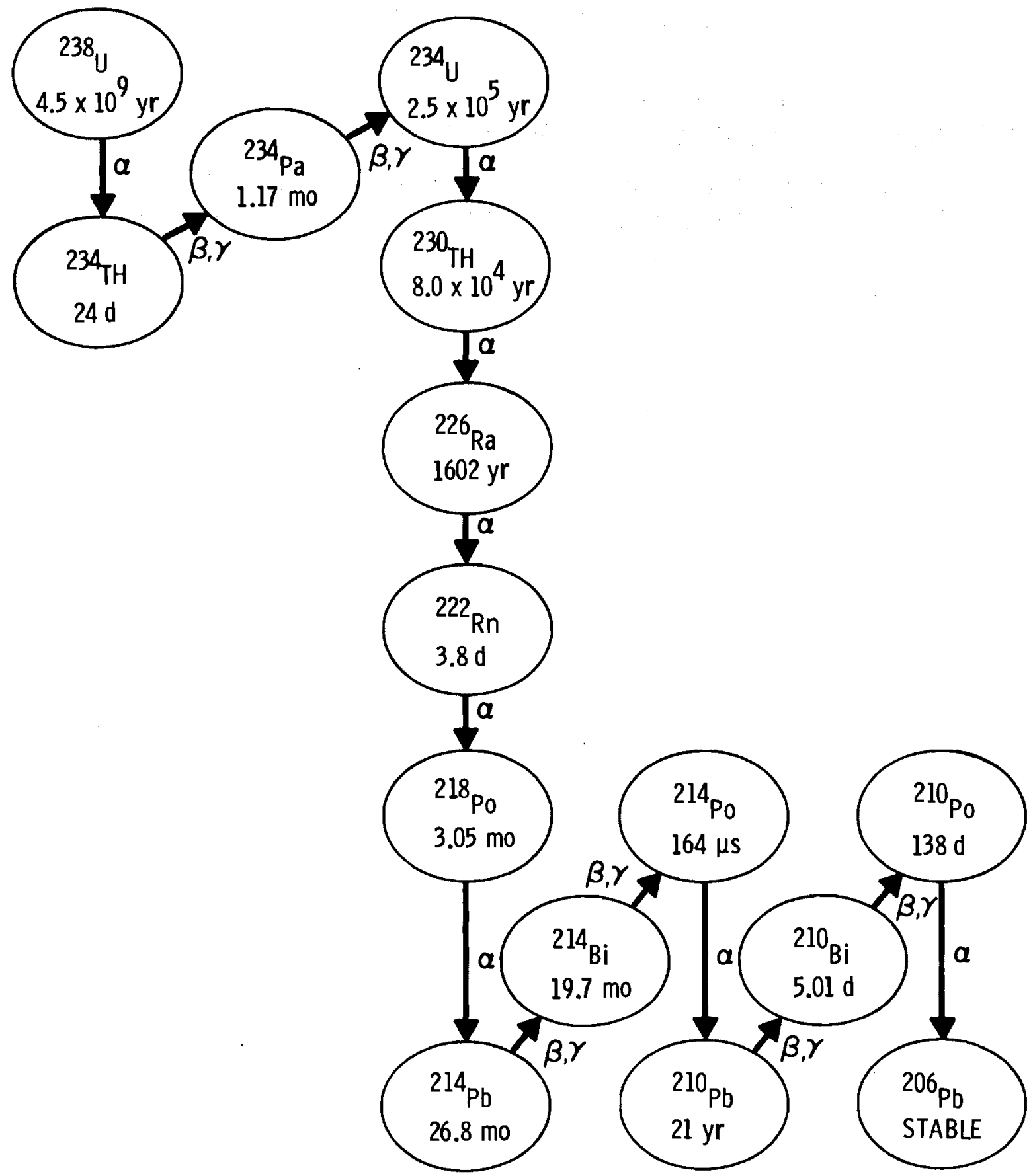

FIGURE B.1. Uranium-238 Decay Series 


\section{REFERENCES FOR APPENDIX B}

National Council on Radiation Protection and Measurement. 1976. Environmental Radiation Measurements. NCRP 50, Washington, D.C.

U.S. Energy Research and Development Administration (ERDA). 1975. Conference on Occupational Health Experience with Uranium. ERDA-93, Washington, D.C. 


\section{APPENDIX C}

THE DOSIMETRY OF URANIUM IN THE BODY 
APPENDIX C

\section{THE DOSIMETRY OF URANIUM IN THE BODY}

In the present context, radiation dosimetry is defined as the assessment of the amount of energy imparted to body tissues by the radioactive decay of unstable isotopes. The dosimetry of uranium and its decay series daughter products involves the measurement or estimation of energy deposited by gamma rays, $x$ rays, beta particles, and alpha particles that are emitted as the isotope undergoes nuclear transformations. Since the biological effects of these radiations are directly related to the amount of energy deposited per gram of tissue, the quantification of dose is important in radiation protection. The absorbed dose is expressed in units of rads (1 rad $=100 \mathrm{ergs} / \mathrm{gram}$ ) or Grays (1 Gy = 1 joule $/ \mathrm{kg}=100 \mathrm{rad})$.

Radiation doses from sources outside the body are measured with radiation detection devices. Estimates of whole-body doses received by uranium workers from external sources of penetrating gamma radiation can be determined from personnel dosimeters worn on the body, or from gamma surveys of work areas and a record of the time spent by workers in those areas.

If radioactive source materials are emitting alpha and beta particles inside the body, the resulting radiation dose to organs and tissues can only be estimated from in-vivo determinations. Direct measurement of alpha and beta emitters is complicated because the range of these particles in tissue is short (microns to millimeters). The energy of these particles is therefore absorbed in the tissues. Photons from ${ }^{235} \mathrm{U}$ and ${ }^{234} \mathrm{Th}$ inside the body can be detected by whole-body counting.

Internal dosimetry involves two major tasks: 1) determining the amount and distribution of radioactive material located in a given region of the body, and 2) determining the amount of energy delivered to surrounding tissues by that deposition during a specific period of time.

Radionuclides can enter the body by inhalation, ingestion, or puncture wounds through the skin. The mode of intake determines which organs or systems will be affected most and, ultimately, the pattern of deposition and clearance 
of the materials from the body. For uranium workers, the primary concern is inhalation. The remainder of this discussion therefore relates to the assessment of dose due to the inhalation of uranium compounds.

Breathing rates, respiratory tract geometry, particle size distribution, and aerosol properties combine to determine the fate of airborne radioactive material that may be deposited in the respiratory system. The chemical solubility and size of the inhaled particles determine whether the material will be cleared by the mucous stream and swallowed, or dissolved by lung fluids and transferred to the Iymphatic or blood circulatory systems. The Task Group on Lung Dynamics of the International Commission on Radiological Protection (ICRP) developed a compartmental model of the body for determining the fate of inhaled chemical compounds (ICRP 1966). The group calculated rate constants for the transfer of inhaled particles between the respiratory system, lymph glands, blood, and gastrointestinal tract. Their lung model was revised and modified in ICRP Publication 19 and ICRP Publication 30 (1972 and 1979). Compounds were separated into three broad categories according to their retention in the lung: class $Y$ for substances cleared slowly, class $W$ for those cleared at moderate rates, and class $D$ for those cleared rapidly. Removal half-times assigned to each class were $\geq 100$ days, 10 to 100 , and $\leq 10$ days, respectively. Some experimental data show, however, that simplified models do not adequately predict deposition, retention, clearance, and excretion for many radioactive compounds. The uranium compounds and decay products of radium are among the most difficult aerosols to categorize for purposes of internal dosimetry. As mentioned previousiy in this report, the temperature of calcination and the chemical form of uranium compounds may strongly influence their solubility (and therefore their body metabolism). Another difficulty encountered in the use of models involves host-specific differences that should be (but usually are not) taken into account, for example, differences in clearance rates due to the health, age, and sex of the host, and other factors such as smoking habits.

After the quantity of radioactive material in a given region of the body has been established, the radiation energy delivered to surrounding biological targets of interest can be quantified. Factors that must be considered include 
the type of radiation and its initial energy, the decay constant, the effective biological half-life, the formation of radioactive daughter products, the spatial distribution of particulate sources in the region, and the physical characteristics of the energy-absorbing medium. The mass of the irradiated tissues and their density must be specified, as well as the time period over which the integral dose is to be calculated. The isotopic ratio of ${ }^{238} \mathrm{U}$, ${ }^{234} \mathrm{U}$, and ${ }^{235} \mathrm{U}$ is important in the dosimetry of enriched uranium.

For gamma-emitting sources in the body, the dose to an organ or tissue includes not only the contribution from sources within the organ itself, but also the dose from sources deposited within surrounding organs. Publications 26 and 30 of ICRP (1977 and 1979) provide mathematical methods for calculating cross-organ doses.

An example of a formula for calculating average organ doses from internally deposited radionuclides is:

$$
\text { dose }(\text { rads })=\frac{51.2 \bar{E} f g A}{W} \int_{0}^{t_{d}} B(t) d t
$$

where 51.2 is a constant conversion factor, $\dot{\bar{E}}$ is the average energy of the particle (MeV), $f$ is the absorbed fraction of the radiation in the site, $g$ is the fractional yield of the emission, $A$ is the initial burden of radioactivity $(\mu C i)$ in an organ of mass $W$ (grams), and $B(t)$ is the retention of the material as a function of time (days). The result is an average organ dose value. However, the organ is rarely irradiated uniformly. Much of the tissue receives no radiation dose at all, while the irradiated portions may receive doses much higher than the average value for the whole organ given by the formula.

For the nonpenetrating alpha- and beta-emitting radionuclides, the particle energy, stopping power of the tissue, and detail of track structure become important in the specification of radiation dose. On a microscopic scale, wide fluctuations are found in the specific energies actually imparted to critical biological targets (such as radiosensitive cells or nuclei within cells) from densely ionizing charged particles. Simple dose averaging fails to account for these wide variations in dose, which are ultimately responsible 
for whatever radiation effect is observed macroscopically. Methods have recently been developed for calculating the microdosimetry of inhaled alpha and beta emitters (Fisher 1980). These methods permit a more exact description of the internal dose distribution.

\section{CONCLUSIONS}

External and internal dosimetry are important aspects in the radiation protection of workers in the nuclear industry. Internal dosimetry, however, is complex. Many factors must be taken into account to achieve even a crude estimate of the dose from internally deposited radioactive materials. No simple guidelines or methods are available for calculating internal doses with precision, particularly in the case of alpha and beta emitters. Conventional dose averaging fails to provide a satisfactory indicator of the specific doses to sites in tissues that result in observable biological effects.

Although considerable progress has been made in radiation dosimetry, much additional work remains to be accomplished (Spitz et al. 1980). This work should include improved characterization of the retention, distribution, and clearance of uranium compounds (particularly yellowcake) in man, and further studies of the microscopic patterns of energy distribution in small but biologically important sites in tissue. 


\section{REFERENCES FOR APPENDIX C}

Fisher, D. R. 1980. "Applied Stochastic Microdosimetry of Internal Alpha Emitters." Presented at 25th Annual Meeting of Health Physics Society, Seatt le, Washington. PNL-SA-8321, Pacific Northwest Laboratory, Richland, Washington.

International Commission on Radiological Protection, Task Group on Lung Dynamics. 1966. "Deposition and Retention Models for Internal Dosimetry of the Human Respiratory Tract." Health Phys. 12:173-207.

International Commission on Radiological Protection. 1972. The Metabolism of Compounds of Plutonium and Other Actinides. Publication 19. Pergamon Press, 0xford.

International Commission on Radiological Protection. 1977. Recommendations of the International Commission on Radiological Protection. Publication 26. Pergamon Press, 0xford.

International Commission on Radiological Protection. 1979. Limits for Intake of Radionuclides by Workers. Publication 30. Pergamon Press, 0xford.

Spitz, H. B., B. Robinson, D. R. Fisher and K. R. Heid. 1980. "Investigation of the Solubility of Yellowcake in the Lung of Uranium Mill Workers by Assay for Uranium in Urine and In Vivo Photon Measurements of Internally Deposited Uranium Compounds." In Proceedings of the Fifth International Congress of the International Radiation Protection Association, Jerusalem, Israel, March 9-14, 1980. 
$\checkmark$ 


\section{DISTRIBUTION}

No. of

Copies

OFFSITE

A. A. Churm

DOE Patent Division

9800 S. Cass Avenue

Argonne, IL 60439

J. R. Blair, M.D.

DOE Headquarters

Mail Station C-201, Routing EV-31

Washington, DC 20545

H. Wolfe, M.D.

DOE Office of Health and Environmental Research

Mail Station E-201

Washington, DC 20545

H. Clark

DOE Oak Ridge Operations Office

P.0. Box E

Oak Ridge, TN 37830

D. M. Cox

DOE Oak Ridge Operations Office

P.0. Box E

Oak Ridge, TN 37830

H. D. Fletcher

Director, Uranium Enrichment Operations

DOE Oak Ridge Operations Office

P.0. Box E

Oak Ridge, TN 37830
No. of

Copies

H. Hickman

Director, Manufacturing Division

DOE Oak Ridge Operations

Office

P.O. Box E

Oak Ridge, TN 37830

J. H. Hil1

Deputy Manager

DOE Oak Ridge Operations Office

P.0. Box E

Oak Ridge, TN 37830

W. A. Johnson

Chief, Occupational Health and Safety Division

DOE Oak Ridge Operations Office

P.0. Box E

Oak Ridge, TN 37830

E. Kiser

Assistant Manager for Development and Planning

DOE Oak Ridge Operations Office

P.0. Box E

Oak Ridge, TN 37830

27 DOE Technical Information Center

J. L. Forbes

Liability Engineering Department

American Nuclear Insurers

Suite 245

270 Farmington Avenue

Farmington, CT 06032 
No. of

Copies

L. Mariani

Vice-President

American Nuclear Insurers

Suite 245

270 Farmington Avenue

Farmington, CT 06032

R. T. Waite

Engineering Consultant

American Nuclear Insurers

42 Middlebrook Road

West Hartford, CT 06119

J. S. Dziewisz

Vice-President

Nuclear Materials and

Manuf acturing Division

Babcock and Wilcox

P.0. Box 1260

Lynchburg, VA 24505

W. F. Heer

Babcock and Wilcox

P.0. Box 1260

Lynchburg, VA 24505

J. Lewis

Manager of Contracts

Babcock and Wilcox

P.0. Box 1260

Lynchburg, VA 24505

D. Pthick

Babcock and Wilcox

P.0. Box 1260

Lynchburg, VA 24505

R. L. Vinton

Health Physicist, N.M.D.

Babcock and Wilcox

P.0. Box 1260

Lynchburg, VA 24505

D. W. Zeff

Manager Safety Licensing and Safe Guards, N.M.D.

Babcock and Wilcox

P.0. Box 1260

Lynchburg, VA 245.05
No. of

Copies

M. Austin

Babcock and Wilcox

Nuclear Materials Division

609 North Warren Avenue

Apol10, PA 15613

R. V. Carlson, M.D.

Babcock and Wilcox

Nuclear Materials Division

609 North Warren Avenue

Apol10, PA 15613

G. J. Bakevich

Combustion Engineering

1000 Prospect Hill Road

Windsor, CT 06095

F. Pianki

General Manager

Combustion Enginering

1000 Prospect Hill Road

Windsor, CT 06095

H. Eskridge

Combustion Engineering

Hematite, MO 63047

J. Cox

Denver Post, Box 1709

Denver, CO 80201

R. Purcel1

Exxon Nuclear Company

2101 Horn Rapids Rd.

Richland, WA 99352

D. Carlson

Farml and Industries

Box 960

Bartow, FL 33830

C. G. Meir

Farmland Industries

Box 960

Bartow, FL 33830 
No. of

Copies

G. E. Wilkinson

Gardinier, Inc.

P.0. Box 3269

Tampa, FL 33601

R. J. Alkema

General Manager

General Electric Company

P.0. Box 780 M/C A09

Castle Hayne Road

Wilmington, NC 28401

J. A. Larson

Manager, Employee and Community Relations

General Electric Company

P.0. Box 780 M/C A09

Castle Hayne Road

Wilmington, NC 28401

P. B. Chandler

Geoscientific Systems and Consulting

8405 Pershing Drive, Suite 402

Playa del Rey, CA 90291

Dr. H. Wilhelm

I owa State University

Ames, IA 50010

J. Clevel and

Kerr-McGee Nuclear Coporation

P.0. Box 218

Grants, NM 87020

D. R. Kump

Kerr-McGee Nuclear Coporation

P.0. Box 218

Grants, NM 87020

W. J. Shelley

Director, Regulations and Control

Kerr-McGee Nuclear Corporation

McGee Tower

Oklahoma City, $\mathrm{OH} 73125$
No. of

Copies

J. W. Craig

$P$ lant Manager

Kerr-McGee Nuclear Corporation

Sequoyah Facility

P. 0. Box 267

Gore, OK 74435

C. A. Grosclaude

Health Physics and

Industrial Safety

Kerr-McGee Nuclear Corporation

Sequoyah Facility

P.0. Box 267

Gore, OK 74435

R. Collins

Lamprecht Solution Mine

Rt. 1, Box 650

Three Rivers, TX 78071

P. Durbin, Ph.D.

Room 101, B 1dg. 74B

Lawrence Berkeley Laboratory

1 Cyclotron Road

Berkeley, CA 97420

A. F. Eidson, Ph.D.

Inhalation Toxicology Research Institute

Lovelace Biomedical and

Environmental Research

Institute

P.0. Box 5890

Albuquerque, NM 87115

H. Yeager

Vice President

Mallinckrodt Corporation

St. Louis, MO 63155

R. Carson

Mammoth Cave National Park

Mammoth Cave, KY 42259 
No. of

Copies

R. Beckman

Physical Agents Division

Mine Safety and Health

Administration

P.0. Box 25367

DFC

Denver, CO 80225

M. Boback

National Lead Company of Ohio

P.0. Box 39158

Cincinnati, $\mathrm{OH} 45239$

R. C. Heatherton

Director of Health and

Safety Division

National Lead Company of Ohio

P.0. Box 39158

Cincinnati, $\mathrm{OH} 45239$

K. Yarborough, Ph.D.

Coordinator of National

Park Service Cave Radiation

Research and Monitoring Program

National Park Service,

Southwest Region

P.0. Box 728

Santa Fe, NM 87501

M. Eisenbud, Ph.D.

Professor of Environmental Medicine

New York University Medical Center

New York, NY 10016

P. Strudler

NIOSH/DCDSD

$5600 \mathrm{~F}$ ishers Lane

Rockville, MD 20857

T. A. Felton

Industrial Hygiene and Safety

M/C 507

Nuclear Energy Business Group

175 Curtner Avenue

San Jose, CA 95125
No. of

Copies

P. R. Robinson

Manager, Employee Relations

Program Operations

$M / C 329$

Nuclear Energy Business Group

175 Curtner Avenue

San Jose, CA 95125

B. W. Saterlee

Manager, Relations and Utilities Operations

M/C 8209

Nuclear Energy Business Group

175 Curtner Avenue

San Jose, CA 95125

C. C. Lushbaugh, M.D.

Oak Ridge Associated Universities

P.0. Box 177

Oak Ridge, TN 37830

J. H. Barker

Oak Ridge Gaseous Diffusion Plant

P.0. Box $P$

Oak Ridge, TN 37830

R. W. Levin

Oak Ridge Gaseous Diffusion Plant

P.0. Box P

Oak Ridge, TN 37830

K. W. Sommerfeld

Oak Ridge Gaseous Diffusion Plant

P.0. Box $P$

Oak Ridge, TN 37830

S. S. Stief

Oak Ridge Gaseous Diffusion Plant

P.0. Box $P$

Oak Ridge, TN 37830 
No. of

Copies

T. Aley

Ozark Underground Laboratories

Protem, MO 65733

R. H. Rucker, M.D.

Paducah Gaseous Diffusion Plant

P.0. Box 1410

Paducah, KY 42001

W. F. Thomas

Assistant Plant Manager

Paducah Gaseous Diffusion Plant

Nuclear Division

P.0. Box 1410

Paducah, KY 42001

S. Brown

Manager, Western Regional Office

Radiation Management Corporation

3110 S. Wadsworth Boulevard

Suite 201

Denver, CO 80227

C. Pomroy

Radiation Protection Bureau, Health and Welfare

Brookfield Rd.

Ottawa, Ontario KIA ICI

CANADA

M. Remley, M.D.

Rockwell International

Energy Systems Group

8900 DeSoto Avenue

Canoga Park, CA 91304

Saskatchewan Research Council Library

30 Campus Drive

Saskatchewan, S7N 0X1

CANADA

R. E. Brubaker, M.D.

UNC Naval Products

67 Sandy Desert Road

Uncasville, CT 06382
No. of

Copies

D. Ganley

Plant Manager

UNC Naval Products

67 Sandy Desert Road

Uncasville, CT 06382

W. Leaders

UNC Recovery Corporation

P.0. Box 765

Mulberry, FL 33860

E. E. Kennedy

United Nuclear - Homestake

Partners

P.0. Box 98

Grants, NM 87020

R. Pollard

Texas Uranium Operations

United States Steel Corporation 600 Winnebago St.

Corpus Christi, TX 78401

H. C. Hodge, Ph.D.

School of Medicine

University of California

Department of Pharmacology

San Francisco, CA 94143

N. Wald, M.D.

University of Pittsburgh

University Radiation Safety

Committee

Office of Research Sponsored

Project

3500 Victor Street

Pittsburgh, PA 15261

J. Caverno

Westinghouse Electric

Corporation

P.0. Box 355

Pittsburgh, PA 15230

A. T. Sabo

Westinghouse Electric

Corporation

Nuclear Safety Division

P.0. Box 355

Pittsburgh, PA 15230 
No. of

Copies

W. L. Goodwin

Nuclear Fuel Division

Westinghouse Electric

Corporation

Power Systems

Bluff Road, Drawer R

Columbia, SC 29250

J. H. Mitche 11

Mine Manager

Wyoming Mineral Corporation

P.0. Box 187

Bruni, TX 78344

R. Platskee

Wyoming Mineral Corporation

Bingham Mine

Copperton, UT 84006

W. R. York

Wyoming Mineral Corporation

Box 960

Bartow, FL 33830

A. M. Ostfeld, M.D.

Professor of Epidemiology and Public Health

Yale University School of Medicine

60 College Street

New Haven, CT 06510

B. W. Karrh, M.D.

Medical Division

Nemours Building 11400

Wilmington, DE 19898

C. E. Newton

2522 Harris

Richland, WA 99352

J. H. Surber

Production Manager, Uranium

P.0. Box 1035

Mulberry, FL 33860

J. H. Thomas

P lant Manager

P.0. Box 430

Metropolis, IL 62960
No. of

Copies

J. Viren, Ph.D.

4701 Connecticut Ave., N.W.

Apartment 401

Washington, DC 20008

R. L. Wechsler, M.D.

Oakland Professional Building

220 Meyran Avenue

Pittsburgh, PA 15213

ONSITE

2 DOE Richland Operations Office

H. E. Ransom

J. D. White

56 Hanford Environmental Health

Foundation

B. D. Breitenste in (5)

R. H. Moore (50)

D. G. Quilici

3 Rockwell Hanford Operations

B. F. Campbe 11

J. E. Kinzer

J. D. McIntosh

46 Pacific Northwest Laboratory

J. L. Baer

F. T. Cross

L. G. Faust

D. R. Fisher

W. A. Glass

G. R. Hoenes (5)

S. Marks

W. D. McCormack

D. W. Murphy

H. W. Slater

G. A. Stoetzel (25)

Technical Information (5)

Publishing Coorodination (2) 